\title{
Establishment of Patterned Thalamocortical Connections Does Not Require Nitric Oxide Synthase
}

\author{
Eva M. Finney and Carla J. Shatz \\ Department of Molecular and Cell Biology and Howard Hughes Medical Institute, University of California, Berkeley, \\ California 94720
}

\begin{abstract}
Subplate neurons are early-generated neurons that project into the overlying neocortex and are required for the formation of ocular dominance columns. A subset of subplate neurons express nitric oxide synthase (NOS) and produce nitric oxide (NO), a neuronal messenger thought to be involved in adult hippocampal synaptic plasticity and also in the establishment of certain specific connections during visual system development. Here, we examine whether the NOS-containing subplate neurons are involved in ocular dominance column formation in the ferret visual system. Ocular dominance columns form in ferrets between postnatal day 35 (P35) and P60. NOS expression in the visual subplate is low at birth, increases to a maximum at the onset of ocular dominance column formation, and falls thereafter. Nevertheless, blockade of NOS with daily injections of nitroarginine from P14 to P56 fails to prevent the formation of
\end{abstract}

ocular dominance columns, although NOS activity is reduced by $>98 \%$. To test further a requirement for NOS in the patterning of connections during CNS development, we examined the cortical barrels in the somatosensory system of mice carrying targeted disruptions of NOS that also received injections of nitroarginine; cortical barrels formed normally in these animals. In addition, barrel field plasticity induced by whisker ablation at birth was normal in nitroarginine-injected NOS knock-out mice. Thus, despite the dynamic regulation of NOS in subplate neurons, $\mathrm{NO}$ is unlikely to be essential for the patterning of thalamocortical connections either in visual or somatosensory systems.

Key words: ocular dominance columns; nitric oxide synthase; visual system; barrels; knock-out; nitroarginine; synaptic plasticity
A fundamental question in developmental neurobiology is how specific sets of patterned connections form during development. Ocular dominance columns, the alternating pattern of left- and right-eye inputs to layer 4 of primary visual cortex in binocular mammals, are a well-characterized system in which to study establishment of specific neuronal connections. Early in development, inputs from the right and left eyes are intermingled (LeVay et al., 1978, 1980). Later, via an activity driven, competitive process, the final adult pattern is established (Wiesel and Hubel, 1965; Hubel et al., 1977; LeVay et al., 1980; Stryker and Strickland, 1984; Stryker and Harris, 1986; for review, see Shatz, 1990; Katz and Shatz, 1996; Crair et al., 1998). Recently, subplate neurons have also been shown to be required for the establishment of ocular dominance columns; early ablation of subplate neurons in cats prevents the segregation of right- and left-eye thalamocortical inputs (Ghosh and Shatz, 1992, 1994; Ghosh, 1995). To learn more about how subplate neurons influence

\footnotetext{
Received May 13, 1998; revised Aug. 4, 1998; accepted Aug. 10, 1998.

This work was supported by the National Eye Institute Grant EY02858 to C.J.S. and by a Howard Hughes Medical Institute (HHMI) predoctoral fellowship to E.M.F. C.J.S. is an investigator of the HHMI. We would like to thank Drs. Mark Fishman and Paul Huang for the eNOS and nNOS knock-out mice. We are also indebted to Dr. David Bredt for the gift of the NOS antibody, the NOS enzymatic activity assay protocol, and additional nNOS knock-out animals and to Dr. Nick Chiaia for the mouse barrel field/cytochrome oxidase protocol. Dr. Daniel Feldman generously assisted with statistical analysis of the diaphorase data. Holly Aaron performed the statistical analysis of ocular dominance columns. We thank also Denise Escontrias for her assistance with surgical procedures and animal husbandry.

Correspondence should be addressed to Dr. Carla J. Shatz, Department of Molecular and Cell Biology and Howard Hughes Medical Institute, 221 Life Sciences Addition, University of California, Berkeley, CA 94720.

Dr. Finney's present address: Department of Psychology 0109, University of California-San Diego, La Jolla, CA 92093.

Copyright (C) 1998 Society for Neuroscience $\quad 0270-6474 / 98 / 188826-13 \$ 05.00 / 0$
}

ocular dominance column formation, here we have investigated a possible role for those subplate neurons that are NADPHdiaphorase-positive (Sandell, 1986; Mizukawa et al., 1988; Derer and Derer, 1993; Luth et al., 1995; Yan et al., 1996; Yan and Ribak, 1997; Finney et al., 1998).

NADPH-diaphorase (hereafter called diaphorase)-positive subplate neurons are of special interest because diaphorase has been identified with nitric oxide synthase (NOS), the synthesizing enzyme for nitric oxide (NO) (Bredt et al., 1991; Dawson et al., 1991; Hope et al., 1991). NO has been implicated in the refinement of retinogeniculate connections into the ON-OFF sublaminae of the lateral geniculate nucleus (LGN) during development. Cramer et al. (1995b) demonstrated a developmental regulation of diaphorase-expressing cells in the LGN of the ferret; blockade of NOS activity with the competitive inhibitor nitroarginine reduced the degree of segregation of retinal axons into ON-OFF sublaminae (Cramer et al., 1996). Similarly, Williams et al. (1994) demonstrated a transient expression of diaphorase in the chick tectum; when NOS activity was blocked, the refinement of the retinotectal map was impaired (Wu et al., 1994, 1996). These observations suggest that NO may be involved in the selective retainment or elimination of immature synaptic connections early in development (for review, see Williams, 1996).

$\mathrm{NO}$ is also thought to be crucial for some forms of adult synaptic plasticity, such as long-term potentiation (LTP) in the hippocampus (O’Dell et al., 1991; Schuman and Madison, 1991; Zhuo et al., 1993; Kantor et al., 1996; Son et al., 1996) or long-term depression (LTD) in the cerebellum (Crepel and Jaillard, 1990; East and Garthwaite, 1990; Lev-Ram et al., 1995, 1997; for recent reviews, see Holscher, 1997; Huang, 1997; Wang et al., 1997). NO can also influence the strength of synaptic connections 
in the cortex (Nowicky and Bindman, 1993; Friedlander et al., 1996a; Harsanyi and Friedlander, 1997a) and at the developing neuromuscular junction (Wang et al., 1995). LTP and LTD can be demonstrated also at developing synapses (Bear et al., 1992; Kirkwood et al., 1993; Mooney et al., 1993; Harsanyi and Friedlander, 1997b), including the thalamocortical synapses in the rodent (Crair and Malenka, 1995; Kirkwood et al., 1995). Thus, it is reasonable to ask whether there might be a requirement for $\mathrm{NO}$ not only in adult synaptic plasticity but during development as well, particularly in view of the presence of diaphorase-positive subplate neurons. Perhaps the subplate neurons are necessary for the segregation of LGN axons into ocular dominance columns because subplate neurons supply the cortex with NO. Thus, subplate neuron ablations might prevent ocular dominance column formation by removing NO, a critical intercellular messenger needed for synaptic strengthening or weakening.

Here, we have tested this hypothesis in several ways. First, we examined the time course of expression of NOS by subplate neurons in the ferret visual system. Then, NOS activity was blocked during the period of ocular dominance column formation using the NOS inhibitor nitroarginine. We also examined mice carrying targeted mutations in two forms of NOS: neuronal NOS (nNOS) or endothelial NOS (eNOS) knock-out mice (Huang et al., 1993, 1995). Mice deficient in both the endothelial and neuronal isoforms of NOS have deficits in hippocampal LTP (Son et al., 1996). Abnormal cortical connectivity or plasticity in nNOS $-/-$ and eNOS $-/-$ mice was assessed by examining barrel field formation or response to peripheral follicle removal (Van der Loos and Woolsey, 1973; Woolsey and Wann, 1976). Because multiple isoforms of nNOS exist in addition to the genetically disrupted isoform (Brenman et al., 1996), we also assessed barrel field plasticity in nNOS and eNOS knock-out mice given daily injections of nitroarginine to eliminate virtually all NOS activity. Although onset of NOS expression in the visual subplate and cortex of ferrets correlates well with ocular dominance column formation, we found that ocular dominance columns form normally in nitroarginine-treated ferrets. In addition, barrel field formation and plasticity are unaffected in NOS knock-out mice even when given nitroarginine. Thus, NO is not likely to be involved in the formation or plasticity of these major thalamocortical connections. Moreover, subplate neurons are likely to exert their effects on ocular dominance column formation via an NOindependent mechanism.

\section{MATERIALS AND METHODS}

A total of 41 ferrets and 60 mice were studied. All surgical procedures were performed according to a protocol approved by the Animal Care and Use Committee of the University of California at Berkeley and Public Health Service policy.

Tissue preparation. At the completion of an experiment, animals were deeply anesthetized by an intraperitoneal injection of sodium pentobarbitol (6 grains $/ \mathrm{ml} ; 1 \mathrm{ml} / 10 \mathrm{lb}$; Anthony Products, Arcadia, CA) and perfused transcardially with cold $0.1 \mathrm{M}$ sodium phosphate buffer and then $4 \%$ paraformaldehyde in $0.1 \mathrm{M}$ sodium phosphate buffer.

NADPH-diaphorase histochemistry. Perfused ferret brains were postfixed $1 \mathrm{hr}$ in $4 \%$ paraformaldehyde and sunk in $25 \%$ sucrose. Visual cortex sections were cut sagittally at $25 \mu \mathrm{m}$ on a sliding freezing microtome. Free-floating sections were incubated in $0.1 \mathrm{mg} / \mathrm{ml}$ nitroblue tetrazolium (NBT) (N5514; Sigma, St. Louis, MO), $1.0 \mathrm{mg} / \mathrm{ml}$ $\beta$-NADPH (Sigma), and $0.3 \%$ Triton X-100 (T9284, Sigma) at $37^{\circ} \mathrm{C}$ for 45 min to several hours according to the method of Vincent and Kimura (1992). The reaction was stopped by washing in sodium PBS (8 gm/1 $\mathrm{NaCl}, 2.16 \mathrm{gm} / 1 \mathrm{Na}_{2} \mathrm{HPO} 4 \cdot 7 \mathrm{H}_{2} \mathrm{O}, 0.2 \mathrm{gm} / 1 \mathrm{KCl}$, and $0.2 \mathrm{gm} / 1 \mathrm{KH}_{2} \mathrm{PO}_{4}$ ) for $20 \mathrm{~min}$. Sections were mounted onto subbed slides, dried overnight, counterstained with neutral red (50 040; Chroma-Gesellschaft Schmid and Company, distributed by Roboz Surgical Instrument Company, Washington, DC), dehydrated briefly through graded alcohols, dipped in xylene for $1 \mathrm{~min}$, and coverslipped with Krystalon (EM Diagnostic Systems, Gibbstown, NJ). Coverslips were sealed with clear nail polish.

Quantification of diaphorase-positive cells. Three representative sections from medial to lateral in the visual cortex of postnatal day 5 (P5), $\mathrm{P} 15, \mathrm{P} 25, \mathrm{P} 35, \mathrm{P} 45$, and adult ferrets $(n=2$ each) were reacted as described above for NADPH-diaphorase histochemistry. Cortical layers and diaphorase-positive neurons were drawn using a camera lucida device. For criteria used to determine layer 6/subplate boundaries, see Chun and Shatz (1989a,b) or Luskin and Shatz (1985). Camera lucida drawings were digitized (Apple Color One Scanner; Apple Computer, Cupertino, CA), and the area of each layer was calculated by determining the pixels contained within each layer (circumscribed manually in Metamorph; Universal Imaging Corporation, West Chester, PA) and dividing by the number of pixels in one square millimeter. The number of diaphorase-positive cells was counted manually for each layer. Cells falling on the borders between layers were counted separately; this value was divided by two, with one-half the border cells attributed to the overlying layer and one-half to the underlying layer. The density of diaphorase-positive cells per layer was derived by dividing the total number of diaphorase-positive neurons in each layer by the area of that layer. Final density values for each layer were averaged for each case and then combined to obtain average values for all cases at each age.

NOS immunohistochemistry and colocalization with NADPHdiaphorase. Some sections from ferret brains used for NADPHdiaphorase histochemistry were also used for NOS immunohistochemistry. Tissue prepared for diaphorase histochemistry was then incubated according to the method of Bredt et al. (1990) for $1 \mathrm{hr}$ at room temperature in blocking solution containing $1 \mathrm{mg} / \mathrm{ml}$ bovine serum albumin (A-7888, Fraction V; Sigma), 0.025\% sodium azide (26628-22-8; Mallinckrodt, Paris, KY), 0.3\% Triton X-100 (789704; Boehringer Mannheim, Indianapolis, IN), and 1\% normal goat serum (Vector Laboratories, Burlingame, CA) in PBS. Tissue was incubated in rabbit anti-NOS primary antibody (diluted in blocker at 1:70; a gift from Dr. David Bredt, University of California, San Francisco, CA) at $4^{\circ} \mathrm{C}$ overnight, washed three times in PBS, incubated in goat anti-rabbit secondary antibody (1:200; Vector laboratories), washed three times in PBS, and developed using the Vectastain Elite ABC kit and $0.05 \%$ diaminobenzidine (DAB) (D5905; Sigma) in PBS with $0.01 \%$ hydrogen peroxide. For sections used for both diaphorase and NOS immunohistochemistry, diaphorase was performed first, with incubation times shortened to facilitate visualization of both blue and brown products within the same cells. Longer incubation times tended to stain cells intensely, preventing discrimination of blue from brown reaction products.

Nitroarginine and verapamil injections (see Table 1). Nitroarginine (N5501; Sigma) (10 mg/kg per day) and verapamil (verapamil hydrochloride injection, USP; American Regent Laboratories, Shirley, NY) (5 $\mathrm{mg} / \mathrm{kg}$ per day) were injected daily intraperitoneally into ferrets from P14 to P56 (Table 1). [In earlier experiments, ferrets were injected from P20 to P56 with nitroarginine alone (Table 1).] Verapamil, a calcium channel blocker, is an anti-hypertensive agent and prevents the high blood pressure effects of nitroarginine at these dosages (Cramer et al., 1996). At P56, ferrets were perfused for $\left[{ }^{3} \mathrm{H}\right]$ proline autoradiography. Nitroarginine was injected intraperitoneally at $5 \mathrm{mg} / \mathrm{kg}$ per day into P0 mice within $12 \mathrm{hr}$ of birth and daily thereafter until P7-P17, when they were perfused for cytochrome oxidase or wheat germ agglutinin (WGA)-HRP histochemistry. Control animals were age-matched and either injected with $0.9 \%$ saline (ferrets) or unmanipulated (mice).

NOS enzymatic activity assay (See Figs. 6, 8). The protocol for this NOS assay was that of Huang et al. (1993). Visual cortices from ferrets (contralateral to the eye injection from the same animals in which transneuronal autoradiography was used to examine the ocular dominance columns) or whole brains from 129 SV wild-type (Jackson Laboratories, Bar Harbor, Maine) or NOS knock-out (a gift from Drs. Mark Fishman and David Bredt) mice were suspended in $10 \mathrm{vol}$ of ice-cold buffer [50 mm Tris-HCl, pH 7.4 (T-3253; Sigma), with 1 mm EDTA (E5134; Sigma) and 1 mm EGTA (E4378; Sigma)] and homogenized. One milliliter of homogenized tissue was put into eppendorf tubes and centrifuged at $10,000 \times g$ for $15 \mathrm{~min}$ at $4^{\circ} \mathrm{C}$. Twenty-five microliters of supernatant from each sample were incubated for $15 \mathrm{~min}$ at room temperature in duplicate (with or without $10 \mu \mathrm{l}$ of $6 \mathrm{mM} \mathrm{CaCl}_{2}$ ) with 100 $\mu \mathrm{l}$ of reaction mix. The reaction mix contained $1 \mathrm{mg} / \mathrm{ml} \mathrm{NADPH}(\mathrm{N}-$ 6504; Sigma), $1 \mu \mathrm{l} / \mathrm{ml}^{3} \mathrm{H}$-arginine (30-60 Ci/mmol, A-3680; Sigma), 2 $\mathrm{mm}$ flavin adenine dinucleotide (F-6625; Sigma), 2 mM flavin mononu- 


\begin{tabular}{|c|c|c|c|c|}
\hline Animal & Treatment & $\begin{array}{l}\text { Treatment } \\
\text { period }\end{array}$ & Assessment method & Number \\
\hline \multirow[t]{13}{*}{ ferret } & $\mathrm{U}$ & $\mathrm{P} 25$ & {$\left[{ }^{3} \mathrm{H}\right]$ proline } & 2 \\
\hline & $\mathrm{U}$ & P28 & {$\left[{ }^{3} \mathrm{H}\right]$ proline } & 2 \\
\hline & $\mathrm{U}$ & P36 & {$\left[{ }^{3} \mathrm{H}\right]$ proline } & 2 \\
\hline & $\mathrm{U}$ & P42 & {$\left[{ }^{3} \mathrm{H}\right]$ proline } & 1 \\
\hline & $\mathrm{U}$ & $\mathrm{P} 43$ & {$\left[{ }^{3} \mathrm{H}\right]$ proline } & 1 \\
\hline & $\mathrm{U}$ & P46 & {$\left[{ }^{3} \mathrm{H}\right]$ proline } & 2 \\
\hline & $\mathrm{U}$ & P56 & {$\left[{ }^{3} \mathrm{H}\right]$ proline } & 2 \\
\hline & $\mathrm{U}$ & P61 & {$\left[{ }^{3} \mathrm{H}\right]$ proline } & 2 \\
\hline & $\mathrm{U}$ & P67 & {$\left[{ }^{3} \mathrm{H}\right]$ proline } & 2 \\
\hline & $\mathrm{S}$ & P14-P56 & {$\left[{ }^{3} \mathrm{H}\right]$ proline } & 2 \\
\hline & S & P20-P56 & {$\left[{ }^{3} \mathrm{H}\right]$ proline } & 2 \\
\hline & $\mathrm{N}$ & P20-P56 & {$\left[{ }^{3} \mathrm{H}\right]$ proline } & 5 \\
\hline & $\mathrm{N}, \mathrm{V}$ & P14-P56 & {$\left[{ }^{3} \mathrm{H}\right]$ proline } & 4 \\
\hline \multirow[t]{7}{*}{ mice nNOS $-/-$} & $\mathrm{U}$ & P3 & Cytochrome oxidase & 6 \\
\hline & $\mathrm{U}$ & P20 & Cytochrome oxidase & 1 \\
\hline & $\mathrm{U}$ & P27 & Cytochrome oxidase & 1 \\
\hline & $\mathrm{N}, \mathrm{W}$ & $\mathrm{P} 0-\mathrm{P} 4$ & Cytochrome oxidase & 5 \\
\hline & $\mathrm{N}, \mathrm{W}$ & P0-P6 & Cytochrome oxidase & 6 \\
\hline & $\mathrm{N}, \mathrm{W}$ & P0-P8 & Cytochrome oxidase & 2 \\
\hline & $\mathrm{N}, \mathrm{W}$ & $\mathrm{P} 0-\mathrm{P} 10$ & Cytochrome oxidase & 2 \\
\hline \multirow{4}{*}{ mice eNOS $-/-$} & $\mathrm{U}$ & P3 & Cytochrome oxidase & 2 \\
\hline & $\mathrm{U}$ & P28 & Cytochrome oxidase & 1 \\
\hline & $\mathrm{N}, \mathrm{W}$ & $\mathrm{P} 0-\mathrm{P} 9$ & Cytochrome oxidase & 3 \\
\hline & $\mathrm{N}, \mathrm{W}$ & $\mathrm{P} 0-\mathrm{P} 12$ & Cytochrome oxidase & 2 \\
\hline
\end{tabular}

$\overline{\left[{ }^{3} \mathrm{H}\right] \text { proline was injected intraocularly } 10 \mathrm{~d} \text { before completion of treatment, and }}$ transneuronal transport was used to visualize ocular dominance columns in layer 4 of the visual cortex. N, Nitroarginine daily; S, saline daily; U, unmanipulated; V, verapamil daily; $\mathrm{W}$, whisker ablation at $\mathrm{P} 0$. Cytochrome oxidase was used to reveal barrels in somatosensory cortex.

cleotide (F-2253; Sigma), $2.5 \times 10^{-3} \mu \mathrm{g} / \mathrm{ml}$ calmodulin (P1915; Sigma), and $0.05 \mathrm{~mm}$ tetrahydrobiopteran (CN-250; Biomol, Plymouth Meeting, $\mathrm{PA})$. The reaction was stopped with $3 \mathrm{ml}$ of deionized water. The reaction solution was loaded onto a column (2083366050; Evergreen Scientific, Los Angeles, CA) of $0.5 \mathrm{ml}$ of Dowex-50W resin (sodium form) (50X8-400; mesh size 200-400; Sigma) and allowed to drip through into glass scintillation vials. (To generate the sodium form of Dowex, the resin was suspended in water and stirred with $\mathrm{NaOH}$ pellets until $\mathrm{pH}$ 12. The resin was allowed to settle, and water was decanted. Rinses were repeated until pH 7 was reached.) Sixteen milliliters of scintillation cocktail were added to each sample. Samples were counted with 1-5 min sampling times on a Beckman Instrument (Palo Alto, CA) LS5000 TD scintillation counter. NOS activity was calculated as counts in the presence of calcium chloride minus counts without calcium chloride. Because NOS is calcium-dependent (Bredt and Snyder, 1990), counts without calcium chloride constituted nonspecific background. Activity was expressed as a percent of control levels (age-matched unmanipulated or saline-injected animals).

Eye injections. The method of transneuronal transport after intraocular injection of $\left[{ }^{3} \mathrm{H}\right]$ proline was used to label ocular dominance columns in layer 4 of the visual cortex (LeVay et al., 1978). [ $\left.{ }^{3} \mathrm{H}\right]$ proline (TRK.534; Amersham Life Science, Little Chalfont, Buckinghamshire, England) was concentrated in a speed vacuum and reconstituted in sterile $0.9 \%$ saline. Ferrets were anesthetized with isoflurane (3\%) and oxygen (1 $1 / \mathrm{min}$ ), and the area around one eye was shaved and sterilized with nolvalsan and alcohol. $\left[{ }^{3} \mathrm{H}\right]$ proline was injected into the posterior chamber of one eye, both nasally and temporally ( 6 and $6.5 \mathrm{ml}$, respectively; 2 $\mathrm{mCi}$ total) using a Unimetrics (Anaheim, CA) or Hamilton (Reno, NV) $50 \mu \mathrm{l}$ syringe with a 33 gauge needle. Survival time after injection was 7-10 d.

Autoradiography. Perfused ferret brains were post-fixed overnight in $4 \%$ paraformaldehyde and then sunk in $25 \%$ sucrose in $0.1 \mathrm{~m}$ sodium phosphate buffer. Visual cortex sections were cut sagittally at $25 \mu \mathrm{m}$ on a sliding freezing microtome, mounted onto subbed slides, defatted through graded alcohols and xylenes, and dipped for autoradiography as described previously (LeVay et al., 1978; Cabelli et al., 1997). After 3-6 weeks, the slides were developed and coverslipped using Permount (Fisher Scientific, Houston, TX).

Quantification of ocular dominance columns. Images of representative sections processed for autoradiography from the visual cortex of saline $(n=4)$ or nitroarginine-treated $(n=9)$ animals (5-18 sections/animal) were acquired with a CCD-72 video camera (Dage MTI, Michigan City, IN) using National Institutes of Health Image software, and ocular dominance columns were quantified as described previously (Cabelli et al., 1995). Briefly, images were spatially smoothed $(5 \times 5$ pixel average $)$, and a brightness profile was derived along a line drawn through the middle of layer 4 (parallel to the pial surface) on each section. The brightness profile was additionally low-pass filtered (HAM; $f_{c}=20 \%$ ) and analyzed with Superscope software (GW Instruments, Somerville, MA), using the first derivative, for (1) periodicity (midpoint-to-midpoint of injected-eye columns), (2) column width (width of individual injectedeye columns), and (3) peak-to-trough amplitude (brightest point of injected-eye columns to darkest point of adjacent uninjected-eye columns, in units of 8-bit pixel gray scale values). To account for possible differences in column parameters across medial to lateral visual cortex, we divided the mediolateral extent of the visual cortex into equivalent thirds (medial, intermediate, and lateral) and analyzed each third separately. Because we found the variability for medial and lateral groups to be much greater than that for the intermediate group, only data from the intermediate group were used in our statistical comparisons. Parameter values for sections within an animal were averaged to acquire a single value per animal. Parameter values for all the saline animals were averaged and compared with the average of all the nitroarginine animals to determine whether significant differences exist. Saline and nitroarginine data were compared using a Student's $t$ test, two-tailed assuming equal variances, $a=0.05$.

Visualization of barrel fields with cytochrome oxidase. Neocortex from perfused mouse brains (see Table 1) was removed and flattened between glass slides overnight in $4 \%$ paraformaldehyde. Flattened cortices were sectioned at $50 \mu \mathrm{m}$ on a sliding freezing microtome. Free-floating sections were reacted for cytochrome oxidase histochemistry $(130 \mathrm{ml}$ of 0.1 M sodium phosphate buffer, $6 \mathrm{gm}$ of sucrose, $75 \mathrm{mg}$ of DAB, and $35 \mathrm{mg}$ of cytochrome C) (cytochrome C from Sigma, C2506) in the dark at $37^{\circ} \mathrm{C}$ according to the method of Chiaia et al. (1992). Reactions were stopped with three rinses in $0.1 \mathrm{M}$ sodium phosphate buffer. Sections were mounted onto subbed slides, dehydrated through graded alcohols and xylene, and coverslipped with Permount.

Whisker ablations. Within $12 \mathrm{hr}$ of birth, mice were anesthetized on ice, an incision was made just ventral to the $\mathrm{C}$ row of whisker follicles with a Moria knife (10315-12; Fine Science Tools, Foster City, CA), and follicles 1-4 were removed with a fine forceps (Jeanmonod et al., 1981). The incision was closed using histoacryl glue. Survival times after ablation were $6-14 \mathrm{~d}$.

\section{RESULTS}

The results are presented in two parts. First, we describe in the ferret visual cortex (1) the time course of ocular dominance column formation, (2) the time course of development of diaphorase-positive subplate neurons, and (3) the consequences of NOS activity blockade on the formation of ocular dominance columns. Second, we present the results of studies of NOS knockout mice that examine (1) barrel field formation in somatosensory cortex, (2) the efficacy of genetic and pharmacological NOS activity blockade, and (3) the consequences for the patterning of thalamocortical connections and plasticity after NOS blockade.

\section{Ocular dominance column formation in ferrets}

To determine whether expression of NOS-positive subplate neurons is developmentally regulated in a way that corresponds to the formation of patterned connections in the visual cortex of ferrets, we first established when ocular dominance columns form in ferrets. To visualize ocular dominance columns in ferrets, we used the technique of transneuronal transport after monocular injection of $\left[{ }^{3} \mathrm{H}\right]$ proline (Fig. 1, Table 1). At the earliest ages 

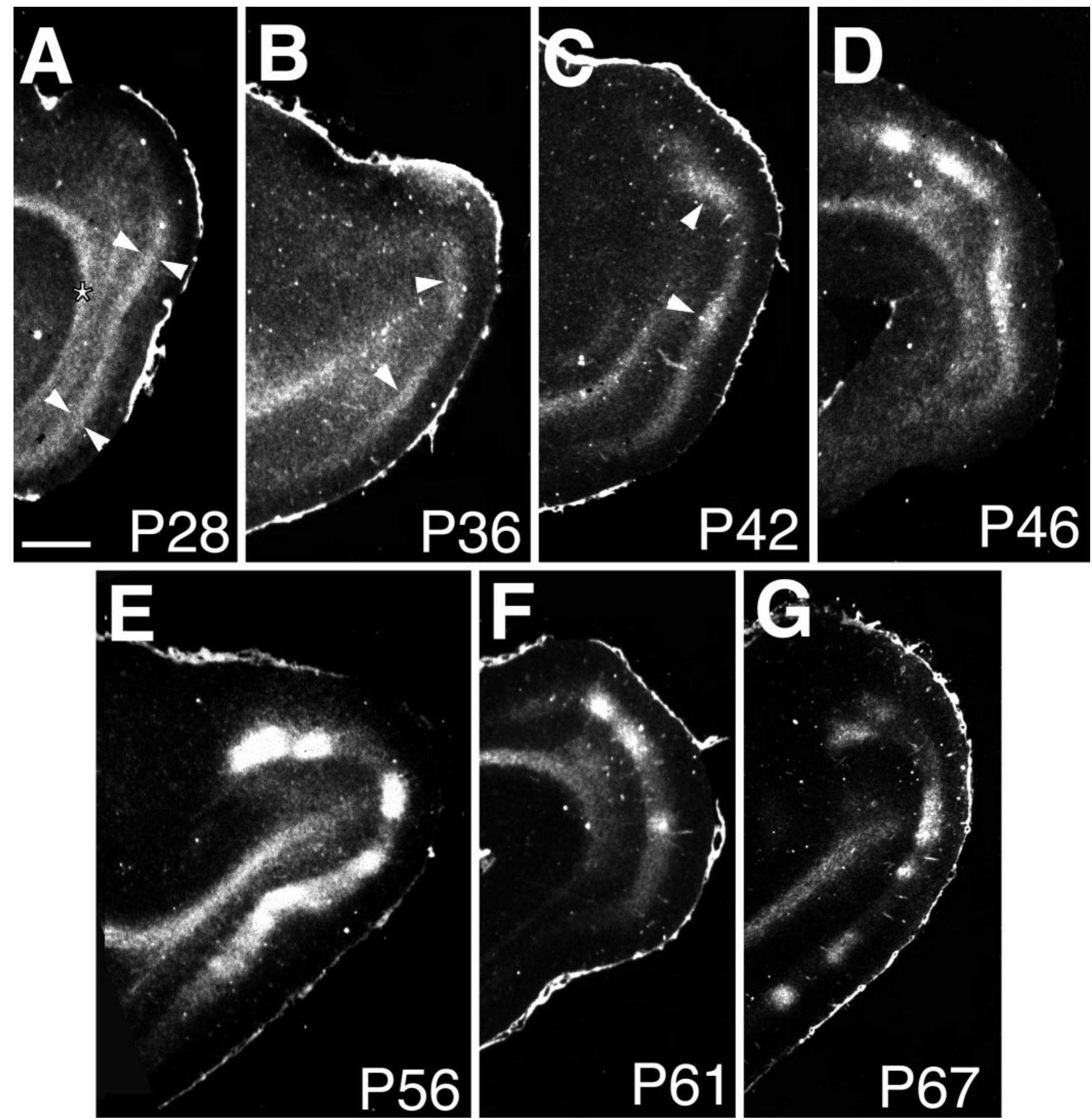

Figure 1. Time course of ocular dominance column formation in ferret visual cortex. Ocular dominance columns are revealed by autoradiography after transneuronal transport of $\left[{ }^{3} \mathrm{H}\right]$ proline injected into one eye (dark-field photographs; silver grains appear white). $A$, At $P 28$, transported label is continuous in layer 4. Arrowheads in $A$ delineate layer 4. B, At P36, patches of label can be detected in layer 4 (arrowheads). $C, D$, At $P 42(C)$ and $P 46$ $(D)$, segregation progresses. Arrowheads in $B$ and $C$ indicate ocular dominance columns belonging to the injected eye. $E-G$, Segregation is pronounced by $P 56(E)$ and P61 $(F)$ and appears adult-like by P67 $(G)$. Anterior is to the left; dorsal is to the top in these sagittal sections. All sections are ipsilateral to the injected eye. The asterisk in $A$ marks labeled geniculocortical axons running in the white matter. Scale bar, $1 \mathrm{~mm}$.

studied, P25 and P28 (1 week before eye opening), ocular dominance columns are not yet present; autoradiographic labeling is continuous in layer 4 of the visual cortex, indicating that LGN axons corresponding to the injected eye have not yet clustered into patches corresponding to the columns. By P36, the first indications of segregation are evident from the presence of periodic variations in the density of silver grains. By P46 and P56, the periodicity is pronounced, and ocular dominance columns are clearly evident in layer 4. By P67, the pattern of labeling is essentially adult-like, with thalamic axons from the injected eye clustered densely to define columns. In the ferret, as in the cat (LeVay et al., 1978), some labeling is evident in layer 4 in territory belonging to the uninjected eye even in the adult. The results of this experiment indicate that ocular dominance col- 

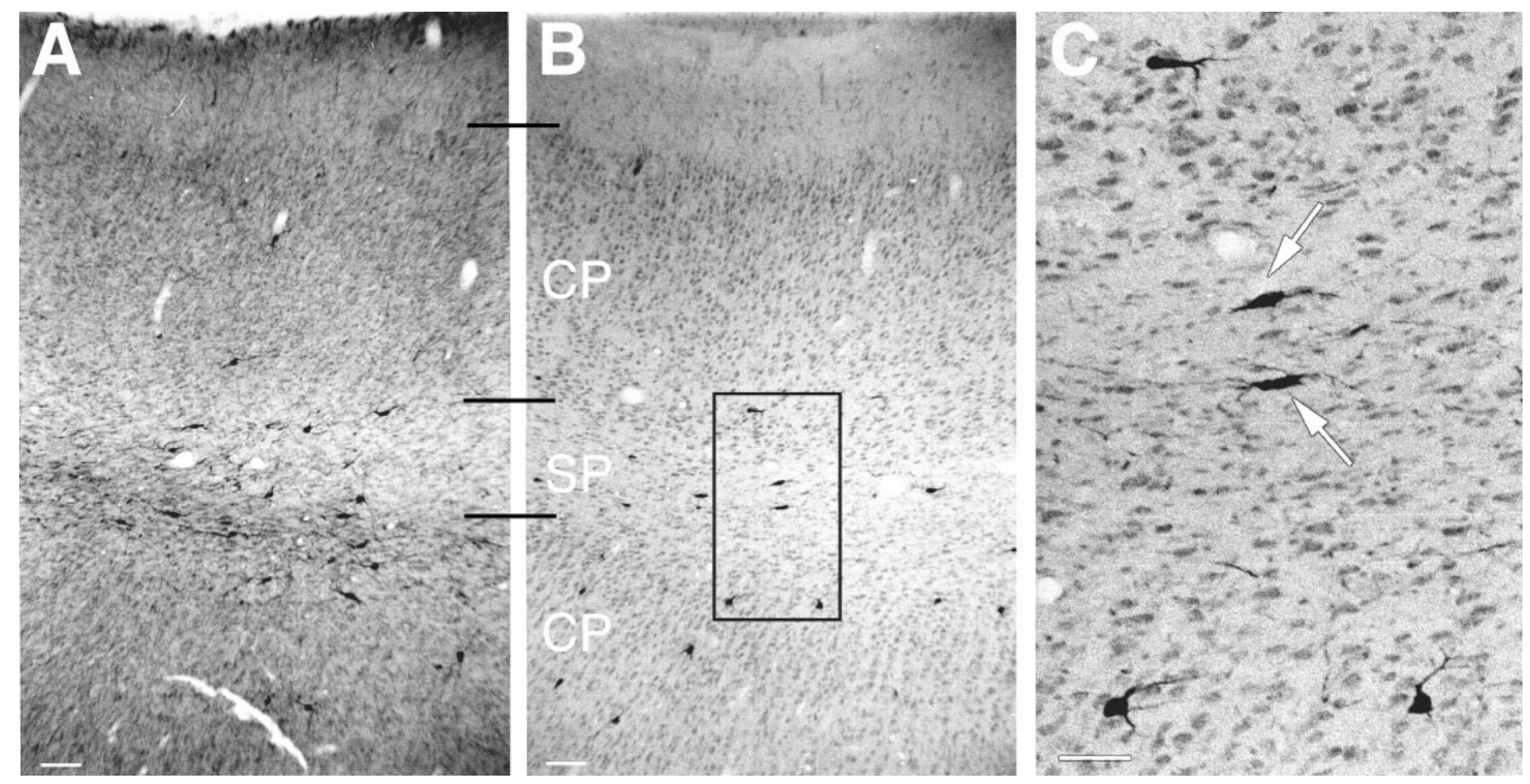

Figure 2. NOS-immunoreactive and NADPH-diaphorase-stained adjacent sections from P36 ferret visual cortex. $A, B$, NOS immunohistochemistry $(A)$ stains cells in a pattern similar to that of diaphorase histochemistry $(B)$. C , Higher magnification view of area boxed in $B$ shows several diaphorase-positive subplate neurons (arrows). Note the typical horizontally oriented processes of these neurons. $B$ and $C$ are counterstained with neutral red to reveal cortical layers. $C P$, Cortical plate; $S P$, subplate. Scale bars, $100 \mu \mathrm{m}$.

umns form between P35 and P60 in the ferret (see also Ruthazer et al., 1995).

Ferret ocular dominance columns, as visualized here in sagittal sections, are less sharp and more irregular than are those in the cat. However, irregular periodicity may be a reflection of sectioning through some columns obliquely rather than perpendicularly. The pattern of ocular dominance columns in the adult ferret has been described previously by Law et al. (1988). They found that ferret columns run in rough stripes that sometimes intersect and vary in width from 200 to $1500 \mu \mathrm{m}$ as viewed from the horizontal plane. Their observations suggest that any single section through the visual cortex of ferrets will produce ocular dominance columns of irregular width. In addition, they reported that $\sim 77 \%$ of the most binocular region contralateral to the injected eye was occupied by label, whereas $49 \%$ was occupied ipsilaterally, suggesting a substantial overlap between the two eyes. This observation agrees with ours that some autoradiographic label representing the injected eye persists in columns dominated by the noninjected eye.

\section{Developmental regulation of NOS in the visual subplate}

We next investigated the time course of expression of NOS in the visual cortex, including the visual subplate, to examine whether there is a correlation in the timing of development of NOSexpressing subplate neurons and formation of ocular dominance columns. NADPH-diaphorase histochemistry [which colocalizes with NOS (Dawson et al., 1991; Hope et al., 1991)] was used to examine the distribution of diaphorase-positive neurons in each cortical layer from P5 to adult. Examples of diaphorase-stained or NOS-immunopositive neurons in the visual cortex of a P36 ferret are shown in Figure 2. Both methods reveal essentially identical patterns of staining, with the majority of neurons at this age located in the subplate. The diaphorase reaction fills neuronal somata and dendrites intensely; the location and morphology of these neurons indicate that they are subplate neurons (Luskin and Shatz, 1985; Chun et al., 1987; Antonini and Shatz, 1990; Allendoerfer and Shatz, 1994; Finney et al., 1998). Diaphorasepositive subplate neurons are multipolar or bipolar, with their long axes usually running parallel to the pial surface. Diaphorasepositive, inverted pyramidal subplate neurons were not observed. Sections reacted for both NOS immunohistochemistry and diaphorase histochemistry reveal neurons labeled with both the blue NBT product of the diaphorase reaction and the brown DAB product of the NOS immunohistochemistry, confirming as in other systems where this has been examined (Dawson et al., 1991; Hope et al., 1991) that both methods stain identical neurons in the visual cortex (data not shown).

The time course of development and the pattern of distribution of diaphorase-positive neurons in ferret visual cortex are shown in the camera lucida drawings of Figure 3. Diaphorase-positive neurons are present at all ages examined from P5 to adulthood ( $n=2$ animals per time point) and in all layers but are especially prevalent in the subplate and layer 6 and are sparse in layers 2-4. These observations are presented quantitatively in Figure 4. The density of diaphorase-positive neurons in the subplate (Fig. 4A) is low at P5 $\left(5.4 \pm 1.9\right.$ per $\left.\mathrm{mm}^{2}\right)$ but increases dramatically by $\mathrm{P} 25$ $\left(37.2 \pm 16.9\right.$ per $\left.\mathrm{mm}^{2}\right)$ and P35 (26.6 \pm 10.0 per $\left.\mathrm{mm}^{2}\right)$, just before the onset of ocular dominance column formation (see above). By $\mathrm{P} 45$, when ocular dominance columns are well on their way to forming, the density of diaphorase-positive subplate neurons has decreased to close to adult levels $\left(\mathrm{P} 45,17.8 \pm 3.7\right.$ per $\mathrm{mm}^{2}$; adult, $15.7 \pm 3.2$ per $\mathrm{mm}^{2}$ ). This fall in the density of labeled subplate neurons between P25 and adulthood is not caused by an increase in the overall area of the subplate. Measurements of subplate area 

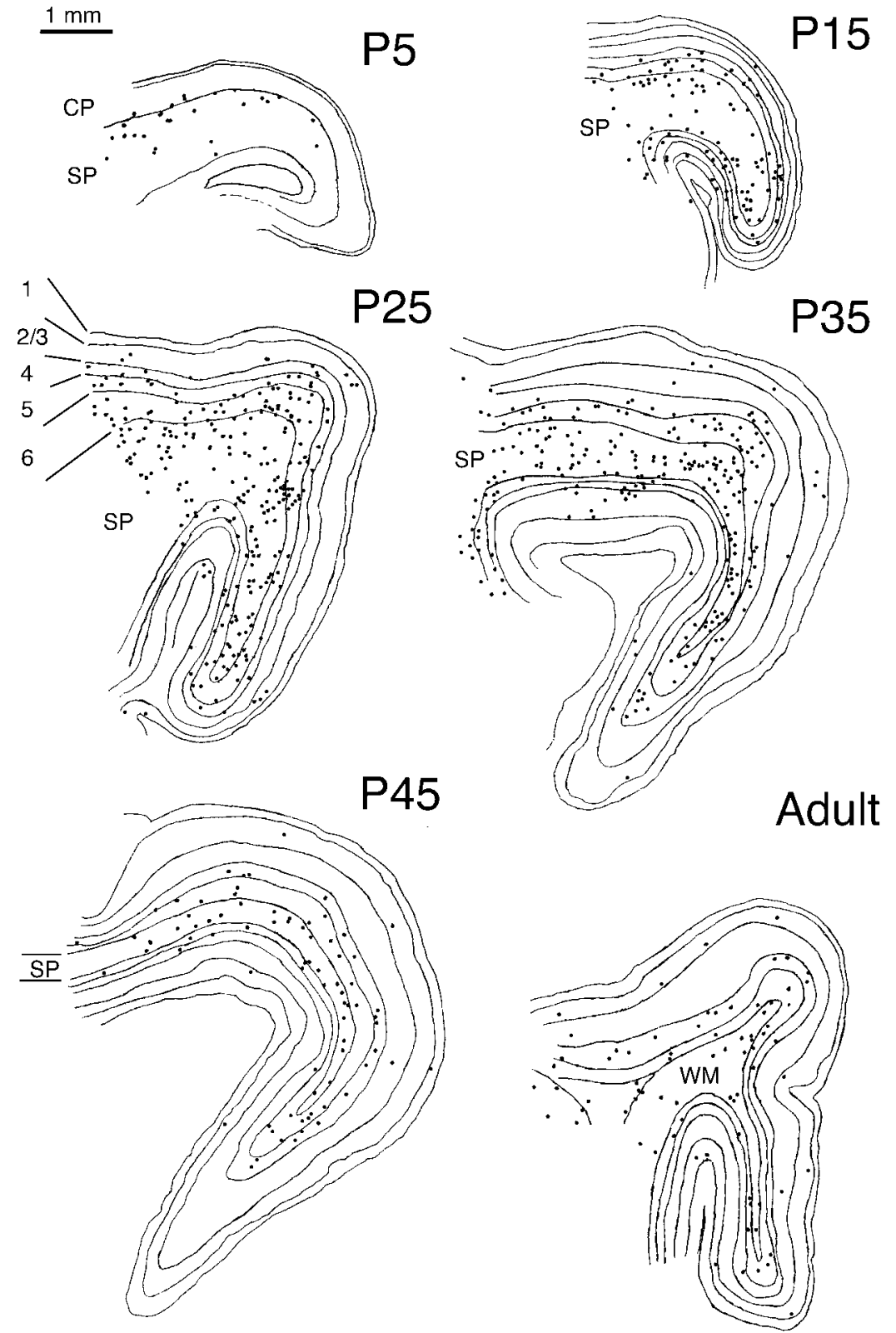

P35

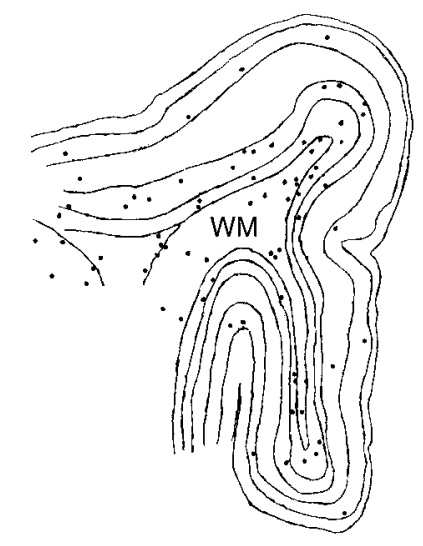

Figure 3. Time course of diaphorase expression in the cortex. Individual camera lucida drawings at various ages of representative diaphorase-stained and neutral redcounterstained ferret visual cortices, similar to the section in Figure $2 B$, are shown. Diaphorase-positive neurons are represented by black dots. Cortical layers are indicated by lines. In the adult, the subplate is labeled $W M$ [white matter (former subplate)]. Diaphorase-positive neurons are present in all cortical layers, most especially in the subplate and deep cortical layers at P25 and P35. All sections are cut in the sagittal plane. Anterior is to the left, and dorsal is to the top. $C P$, Cortical plate; $S P$, subplate; 1-6, the cortical layers, which are only labeled at $P 25$ (although all layers are delineated at each time point except for P5, when cortical layers are ill-defined). Scale bar, $1 \mathrm{~mm}$.
(Fig. $4 B$ ) show that there is a $>50 \%$ decrease in the area of the subplate between P5 and adulthood, consistent with previous observations in other species [cat (Chun and Shatz, 1989b); monkey (Kostovic and Rakic, 1990); human (Kostovic and Rakic, 1990)]. In fact, between P25 and adulthood, the subplate area falls modestly, yet the density of subplate neurons falls dramatically. These observations indicate that the absolute numbers of diaphorase-positive subplate neurons peak between P25 and P35, followed by a decline at subsequent ages. Thus, the onset of ocular dominance column formation coincides with a dramatic fall in the numbers of diaphorase-positive subplate neurons.

\section{Blockade of NOS activity during ocular dominance column formation}

Results described above demonstrate that just before the beginning of ocular dominance column formation in layer 4, many subplate neurons and also neurons in layers 5 and 6 are diaphorase positive. It is possible that the rise and subsequent fall in diaphorase-positive subplate neurons are required to trigger the onset of geniculocortical segregation. To test this hypothesis, we blocked NOS activity by making daily intraperitoneal injections of the NOS competitive antagonist nitroarginine (East and Garthwaite, 1990; Dwyer et al., 1991; Cramer et al., 1996; Moore and Handy, 1997). Two sets of experiments were conducted (Table 1). In the first, nitroarginine alone was injected from P20, before the onset of column formation, to P56. In the second set, the injections were started even earlier, at P14, to cover the entire period during which subplate neurons undergo changes in NOS levels. In this second set of experiments, verapamil was also given to prevent blood pressure fluctuations caused by injections of nitroarginine alone. Coinjection of verapamil and nitroarginine successfully prevents hypertension in ferrets and also reduces the extent of segregation of retinal ganglion cell axons into the ON-OFF sublaminae within the LGN (Cramer et al., 1996).

Nitroarginine injections beginning either at P14 or P20 through P56 had no detectable effect on the segregation of LGN axons into ocular dominance columns, as assessed by means of trans- 

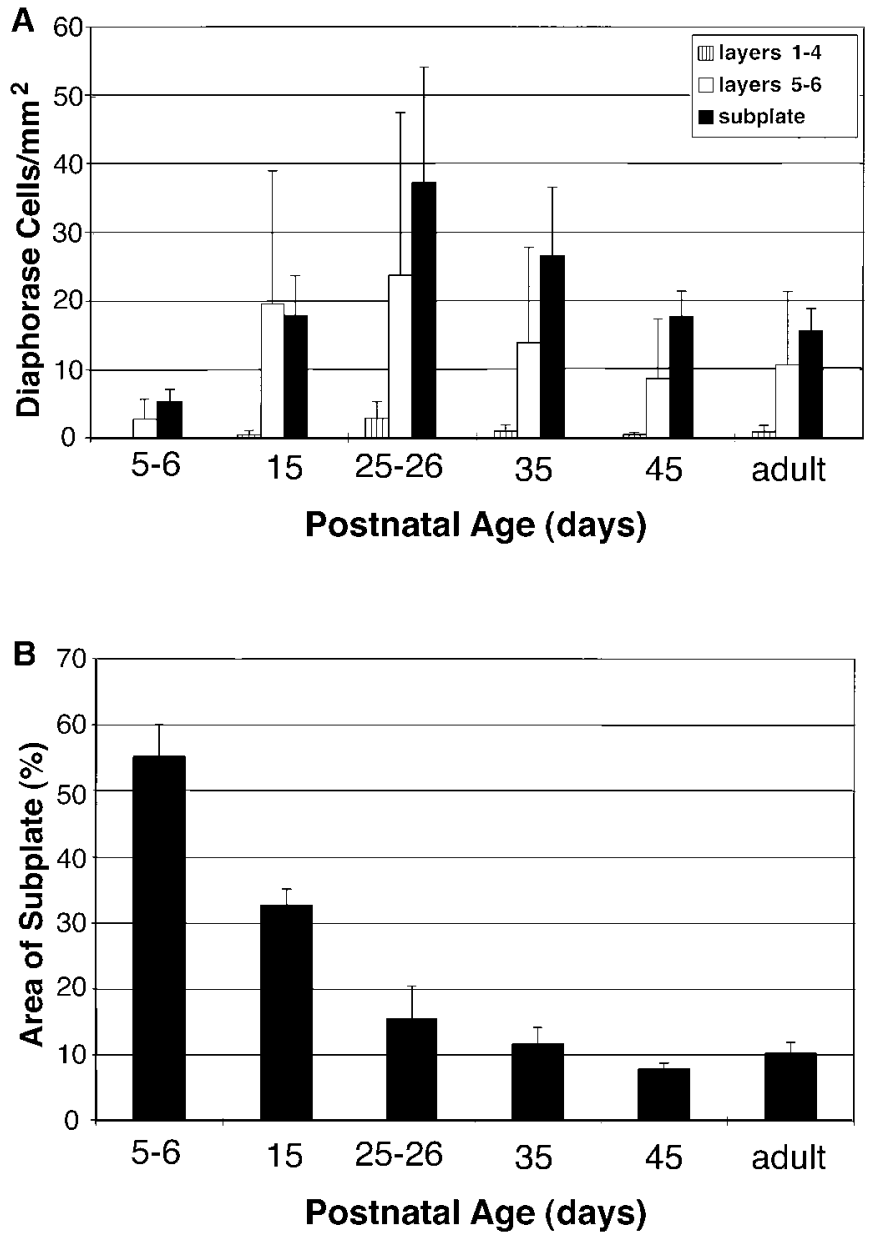

Figure 4. Changes in the density of diaphorase-positive neurons and the area of the subplate during development of ferret visual cortex. $A$, Histogram showing the density of diaphorase-positive neurons in superficial, infragranular, and subplate layers from P5 to adult. At P5, cortical layers consist primarily of layers 5 and 6 . At each age, the mean density of diaphorase-positive cells in the subplate and deep cortical layers is greater than that in cortical layers 1-4. Error bars for this (and all following figures) represent SDs. The differences in the mean subplate values at each age are greater than would be expected by chance (ANOVA; $a=$ $0.05 ; p=0.0001)$. The density of diaphorase-positive neurons in the subplate at P25 is significantly different from that at all other ages (Student-Newman-Keuls test; $p<0.05$ ); in addition, P35 is significantly different from P5 $(p<0.05)$. B, Changes in the area of the subplate underlying the visual cortex with age. The subplate as a percent of the total area of the visual cortex decreases steadily from $\sim 55 \%$ at P5 to $\sim 10 \%$ by adulthood.

neuronal transport of $\left[{ }^{3} \mathrm{H}\right]$ proline after an eye injection (Fig. $5 A, B)$. Because segregation is normally more evident in the hemisphere ipsilateral to the eye injection [because of spillover of label in the contralateral hemisphere into LGN layers receiving input from the uninjected eye (LeVay et al., 1978)], the autoradiographic labeling pattern was compared in the ipsilateral hemisphere of nitroarginine- $(n=9)$ and saline-treated $(n=4)$ animals. Ocular dominance columns in layer 4 of nitroargininetreated animals were statistically indistinguishable from normal ones $(p>0.05)$ in periodicity, width, and peak-to-trough amplitude as shown quantitatively in the histograms of Figure $5 C$.

The interpretation of this result is critically dependent on the effectiveness of the NOS blockade. NOS produces NO and citrulline in stoichiometric amounts from arginine (Bredt and Sny- der, 1990). Because the half-life of NO is in the order of seconds, it is impractical to assay NO production directly. Thus, we assessed NOS activity after nitroarginine treatment from P14 to P56 using a protocol that measures the conversion of $\left[{ }^{3} \mathrm{H}\right]$ arginine to $\left[{ }^{3} \mathrm{H}\right]$ citrulline (Huang et al., 1993). NOS activity was measured in the visual cortex contralateral to the eye injection in the same animals in which transneuronal autoradiography had been used to examine the ocular dominance columns. Despite the presence of normal ocular dominance columns, NOS activity in all cases (Fig. $6 ; n=5$ ) had been reduced by $>95 \%$ compared with that in saline or uninjected controls, and in one case, NOS activity was almost undetectable from background (see Materials and Methods). It is conceivable that the nitroarginine blockade took effect too slowly to prevent the onset of segregation. Thus, six additional ferrets (1 at P14, 2 at P22, 2 at P24, and 1 at P37) were injected with nitroarginine and then assayed for NOS activity 24-48 hr later. NOS activity was in all cases reduced by $90 \%$ or greater, with an average blockade of $95 \%$ (Fig. 6). Once again, one animal had levels of NOS activity actually indistinguishable from background. Consequently, we believe that the treatment produced a rapid, lasting, and effective (up to 95-100\%) blockade before and during the entire period of ocular dominance formation. Because columns form normally, we conclude that, unless the extremely low residual NOS activity is sufficient, NO is not required.

\section{Formation of barrels in the somatosensory cortex of NOS-I- mice}

Because it is still conceivable that small residual NOS activity could be sufficient to permit the segregation of geniculocortical axons into ocular dominance columns, we next examined the formation of thalamocortical connections in the somatosensory cortex of NOS knock-out mice (Huang et al., 1993, 1995). Because multiple isoforms of NOS exist (Lowenstein et al., 1992; Bredt, 1995; Silvagno et al., 1996; Xia and Bredt, 1996; Brenman et al., 1997), we obtained mice deficient in either the neuronal (nNOS) (Huang et al., 1993) or the endothelial (eNOS) (Huang et al., 1995) isoforms of NOS. The development of barrels in the somatosensory cortex was examined by cytochrome oxidase histochemistry (Chiaia et al., 1992). Figure 7 shows that nNOS $(n=$ $6)$ or eNOS $(n=2)$ homozygous knock-outs have barrels present at P12 (see also Table 1), the earliest age that barrels can be normally visualized by this histochemical method. The pattern of barrels seems well defined and of normal size and shape in nNOS or eNOS knock-out mice. Thus, neither the rate of development nor the pattern of barrels is perturbed in these animals.

Barrels might have formed normally in neuronal or endothelial knock-outs because alternate, intact isoforms might have compensated for the missing enzyme activity. At least six different splice variants of nNOS are known, including a form of nNOS not disrupted in the nNOS knock-out (Brenman et al., 1996, 1997); there are also inducible isoforms of NOS found in macrophages (Lowenstein et al., 1992, 1993; Reiling et al., 1994). Thus, we decided to block all NOS activity by injecting nNOS or eNOS knock-out mice with nitroarginine rather than by breeding double n/eNOS knock-out animals. nNOS (Fig. $8 A$ ) and eNOS (Fig. $8 B$ ) knock-out mice received daily injections (within $12 \mathrm{hr}$ of birth) of nitroarginine for 1-7 d. NOS activity in whole brain homogenates of unmanipulated nNOS knock-out mice at $\mathrm{P} 7$ was reduced to $\sim 3 \%$ of wild-type levels (Fig. $8 A, P 7,3.0 \pm 0.2 \% ; n=2$ ). This reduction agrees quite well with previous reports in which a similar arginine-to-citrulline enzymatic assay protocol was used to show that unmanipulated nNOS knock-outs have nNOS catalytic 

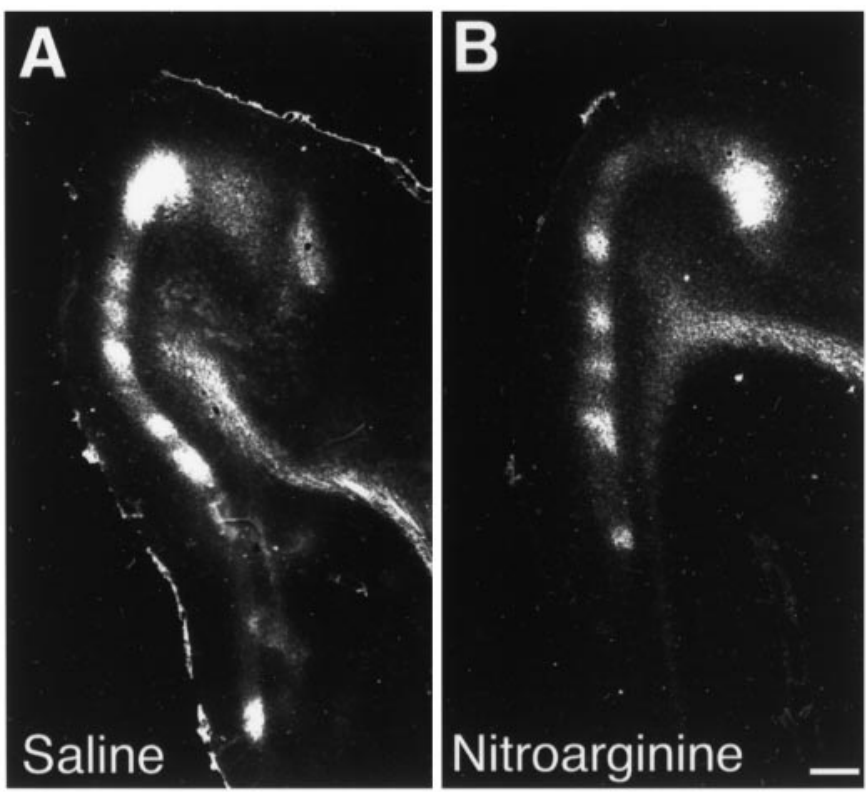

C

Periodicity and Column Width in Saline and Nitroarginine-Treated Animals
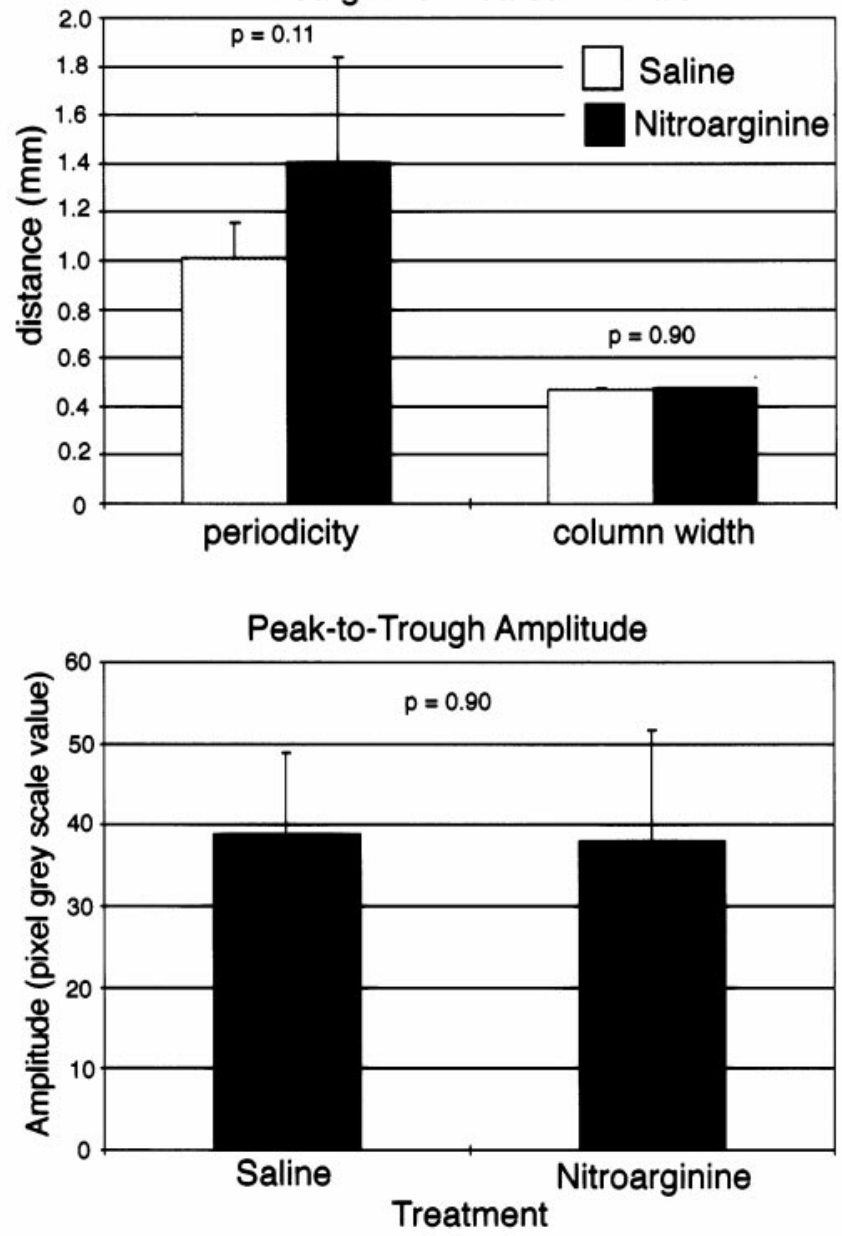

Figure 5. Ocular dominance columns are normal after nitroarginine treatment from P14 to P56. Transneuronal transport after monocular injection of $\left[{ }^{3} \mathrm{H}\right]$ proline was used to reveal the pattern of geniculocortical terminals (dark-field autoradiographs). $A$, Sagittal section through the primary visual cortex of a ferret injected with saline from P14 to P56. $B$,

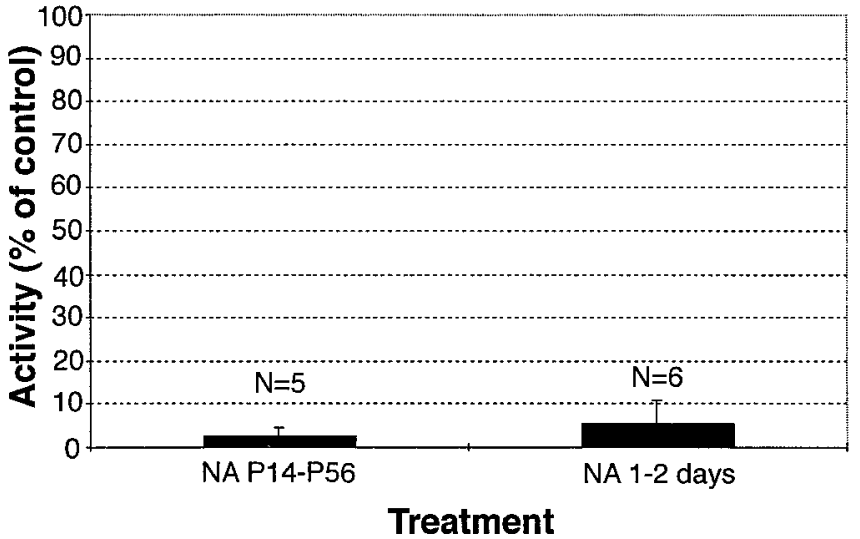

Figure 6. NOS catalytic activity in the visual cortex is reduced to $\sim 2 \%$ of control levels in ferrets treated with nitroarginine from P14 to P56 (left column). (Cortex is from the same animals whose opposite hemisphere was examined for formation of ocular dominance columns.) NOS blockade took effect within $24-48 \mathrm{hr}$ (right column), because NOS activity was reduced by $>90 \%$ in six ferrets ( 1 at P14, 2 at P22, 2 at P24, and 1 at P37) given nitroarginine for 1-2 d. NOS activity was assessed as described in Materials and Methods and is expressed as a percent of that in agematched control (saline-injected or unmanipulated) ferrets. $N A$, Nitroarginine

activity $\sim 0.2-7 \%$ of that in control brains (Huang et al., 1993). Moreover, nNOS knock-outs given daily nitroarginine from $\mathrm{P} 0$ to $\mathrm{P} 7$ had NOS activity reduced to $\sim 1 \%(P 0-P 7 N A, 1.0 \pm 1.4 \%$; $n=4)$ of wild-type activity. After $7 \mathrm{~d}$ of treatment, one nNOS $-/-$ mouse had undetectable levels of NOS activity. Even as early as $24 \mathrm{hr}$ after the beginning of nitroarginine injections, NOS activity had fallen to $\sim 1 \%$ of wild-type levels $(P O+24 \mathrm{hr}$ $N A, 0.8 \pm 0.7 \% ; n=5)$. One nitroarginine-treated nNOS knockout mouse had NOS activity levels indistinguishable from background after just $24 \mathrm{hr}$ of blockade. Thus, combining nitroarginine treatment with the nNOS homozygous animals reduced NOS activity to $\sim 1 \%$ of that in wild-type littermates.

Again, as expected from previous studies (Son et al., 1996), there is significant residual NOS activity in eNOS homozygous knock-out mice (Fig. $8 B, P 7,67.0 \pm 13.9 \%$ of wild type; $n=3$ ). After nitroarginine injections between $\mathrm{P} 0$ and $\mathrm{P} 7$, NOS activity is reduced to $\sim 10 \%$ of that in wild-type mice $(P 0-P 7 N A, 9.8 \pm$ $3.0 \% ; n=4)$. Activity blockade in eNOS mice given nitroarginine is effective within $24 \mathrm{hr}$; eNOS mice examined $24 \mathrm{hr}$ after the onset of nitroarginine treatment had $\sim 6 \%$ residual NOS activity $(P 0$ or $P 1+24 h r N A, 5.7 \pm 0.8 \% ; n=3)$ compared with $\sim 60 \%$ $(P 2,58.4 \pm 7.7 \% ; n=2)$ residual activity in uninjected P2 eNOS $-/-$ animals. These observations indicate that NOS activity is greatly reduced in $\mathrm{nNOS}-/-$ and eNOS $-/-$ mice given nitroarginine from birth (in some cases to levels indistinguishable from background) and that this blockade can be fully effective within 24 hr of birth.

Sagittal section through the visual cortex of a ferret receiving nitroarginine from $\mathrm{P} 14$ to P56. $A$ and $B$ are both from cortex ipsilateral to the eye injection, where segregation into columns is clearest (LeVay et al., 1978). Anterior is to the right, and dorsal is to the top. Scale bar, $500 \mu \mathrm{m}$. C, Quantification of ocular dominance column features (periodicity, column width, and peak-to-trough amplitude) showing that all are indistinguishable from normal features in the nitroarginine-treated animals. See Materials and Methods for quantification details. 

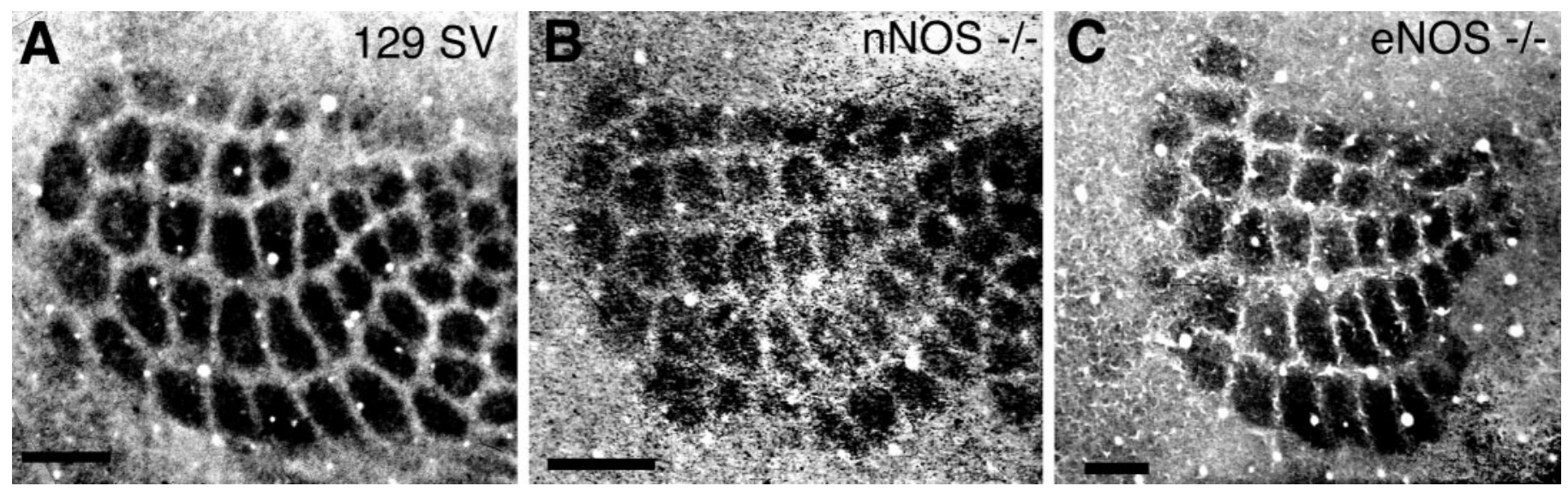

Figure 7. Barrels in the somatosensory cortex of nNOS or eNOS knock-out mice are indistinguishable from those in normal mice. Tangential sections through flattened somatosensory cortex were stained with cytochrome oxidase histochemistry. $A$, Wild-type (129 SV) mouse barrel field at P6. B, nNOS knock-out mouse barrel field at P3. $C$, eNOS knock-out mouse barrel field at P12. Scale bars, $250 \mu \mathrm{m}$.

\section{A. NOS activity in nNOS -/- mice}

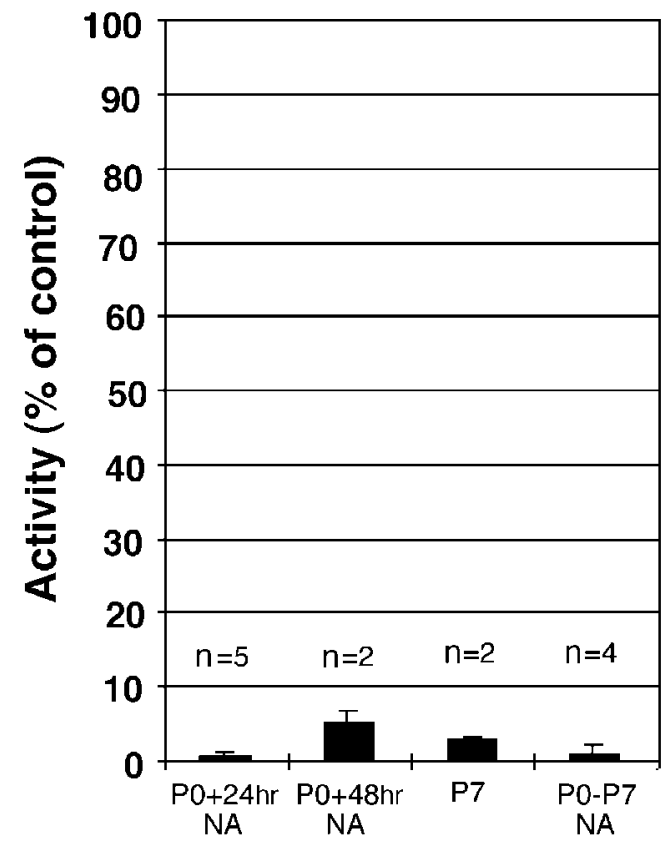

Treatment

\section{B. NOS activity in eNOS -/- mice}

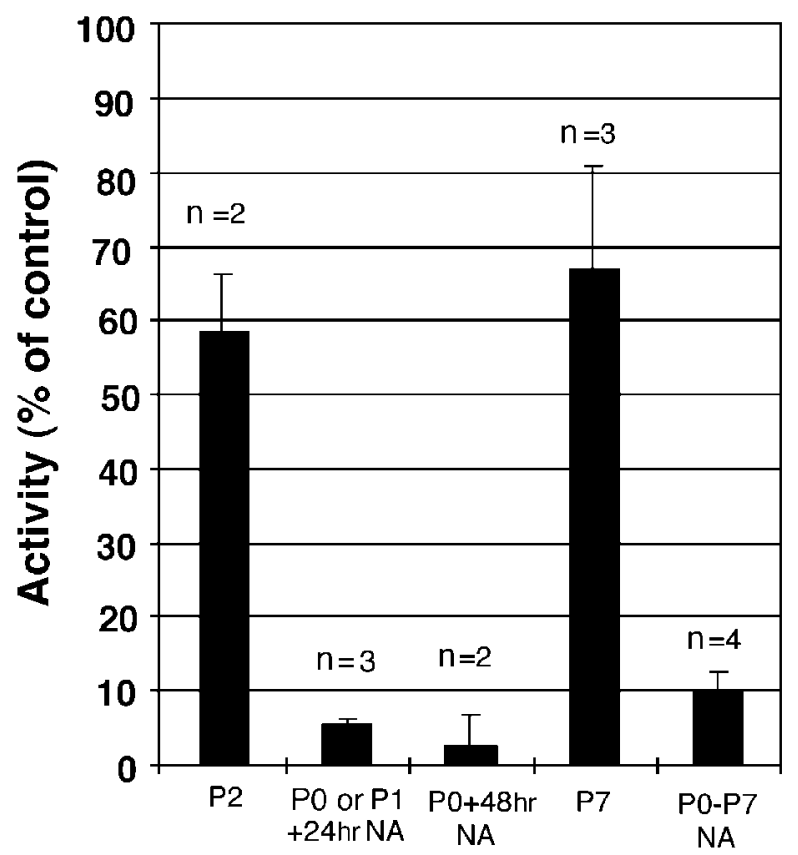

Treatment

Figure 8. NOS activity is greatly reduced in brain homogenates from nNOS $(A)$ or eNOS $(B)$ knock-out mice given daily nitroarginine injections from the day of birth $(P O)$. NOS activities for age-matched uninjected and nitroarginine-injected NOS knock-out animals are presented as pairs. As expected, NOS activity persists in single knock-out animals, especially in eNOS $-/-$ mice. (nNOS $-/-$ mice were examined at $P 7$; eNOS $-/-$ mice were examined at $P 2$ or $P 7$.) However, NOS activity is greatly reduced in nitroarginine-injected nNOS or eNOS homozygous knock-out mice. Nitroarginine blockade was rapid and took effect within $24 \mathrm{hr}$ of birth. Activity is expressed as a percent of that in age-matched, wild-type (129 SV) mice. P0-P7 NA, Mice received nitroarginine daily from $P 0$ to $P 7 ; P 0$ or $P 1+24 \mathrm{hr} \mathrm{NA}$, mice received nitroarginine at $P 0$ or $P 1$ and were assayed for NOS activity 24 hr later; $P 0+48 \mathrm{hrNA}$, mice received nitroarginine daily from birth to $P 2$ (48 hr total).

\section{Formation and plasticity of barrels in NOS} homozygous knock-out mice treated with nitroarginine

Given the fact that nitroarginine treatment from birth can rapidly reduce NOS activity to near baseline values, especially in the nNOS $-/-$ mice, we next examined whether barrels can form in these animals after nitroarginine administration. We designed an experiment in which initial barrel formation and subsequent barrel plasticity could be monitored simultaneously by ablating one row of whiskers at P0 in nNOS or eNOS knock-out mice given nitroarginine daily from birth to P7 (Table 1). When a row of whiskers in the periphery is ablated in wild-type mice at P0, animals develop a dramatically altered barrel field pattern in the cortex in which the barrels corresponding to the ablated row of whiskers shrink, fuse, and sometimes even disappear, and the 

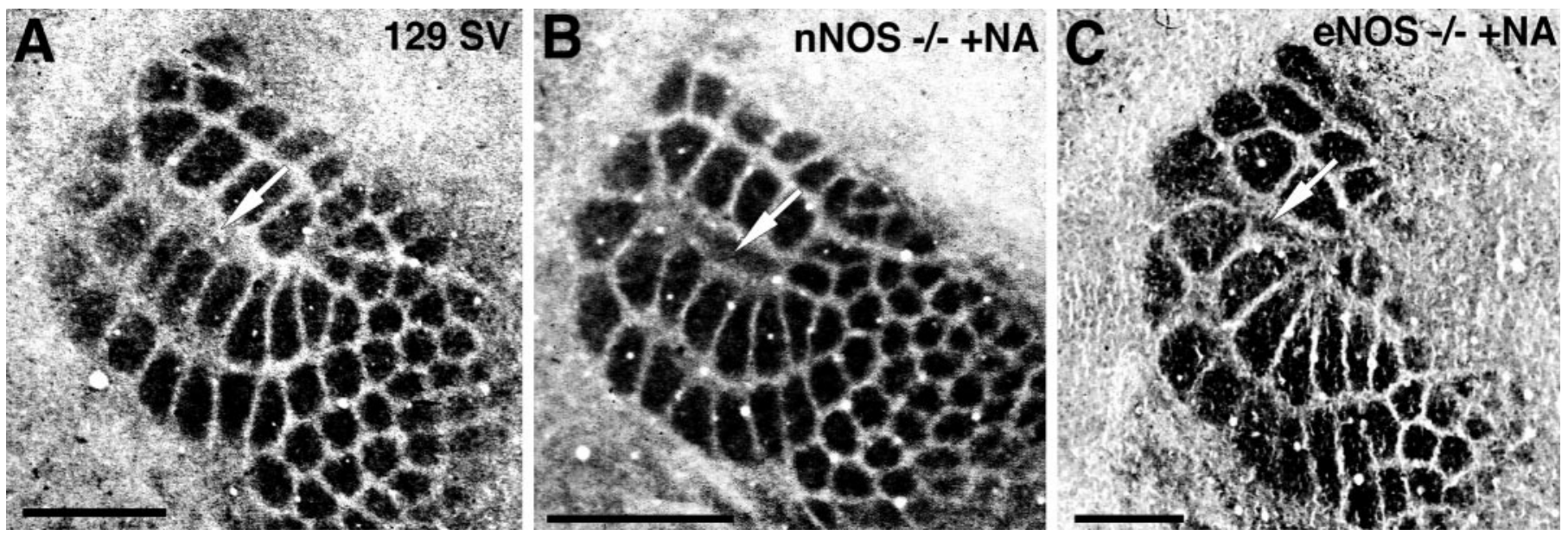

Figure 9. Initial barrel formation and barrel field plasticity persist after nitroarginine treatment in nNOS and eNOS homozygous knock-outs. $C$-row peripheral whisker follicles were removed at P0. A, Barrel fields in a wild-type mouse at P8. $B$, Barrel fields in an nNOS $-/-$ mouse given nitroarginine from P0 to P6. $C$, Barrel fields in an eNOS-/- mouse given nitroarginine from P0 to P12. In each animal, arrows point to fused $C$-row barrel representations. Barrels have formed normally in the unmanipulated $A$ and $E$ rows (top rows), whereas the neighboring $B$ and $D$ rows have expanded to occupy cortical territory originally designated for the shrunken and fused $C$-row barrels. Cytochrome oxidase histochemistry of tangential sections through flattened cortex is shown. Scale bars, $500 \mu \mathrm{m}$.

adjacent barrels enlarge (Fig. 9A) (Van der Loos and Woolsey, 1973; Weller and Johnson, 1975; Woolsey and Wann, 1976; Jeanmonod et al., 1977). Whisker ablation can thus be used as an assay for the ability of central projections to reorganize in response to changes at the periphery. Within the somatosensory cortex of NOS - /- mice treated with nitroarginine, barrels formed normally and exhibited normal barrel field plasticity in response to whisker ablation (Fig. 9B,C). As in wild-type animals (Fig. 9A), whisker rows adjacent to the ablated whiskers (rows $B, D$ ) expanded to occupy the space abandoned by the ablated row. Because NOS catalytic activity in these nitroarginine-injected NOS homozygous knock-out mice is, in some cases, indistinguishable from background, NO is not likely to be required either for normal barrel formation or for barrel field plasticity.

\section{DISCUSSION}

In this study, we have examined a possible role for NO in the formation of patterned connections between thalamus and cortex in the ferret visual system and in the somatosensory system of mice carrying targeted mutations in NOS. Our study was motivated by many previous observations (see introductory remarks) suggesting that NO can be involved in a variety of aspects of activitydependent synaptic plasticity both during development and in adulthood. Nevertheless, the results of our study demonstrate that the initial segregation of geniculocortical axons into ocular dominance columns is not likely to require NO. Moreover, the emergence of the adult pattern and plasticity of thalamocortical connections in the somatosensory system of the mouse is also unlikely to require NO. In both species, we were able to decrease the activity of NOS rapidly (within $24 \mathrm{hr}$ of treatment) by $>95 \%$ and sometimes by $>99 \%$, either by pharmacological blockade with nitroarginine or by examining mice lacking eNOS or nNOS that were also treated with nitroarginine. Unless the residual NOS activity is sufficient, we are forced to conclude that NO is not essential for the development of the adult pattern of thalamocortical connections in either visual or somatosensory systems or for the plasticity induced by whisker ablation in the somatosensory system.

Previous studies have also failed to reveal a role for NO in the development of other sets of connections in the CNS. The devel- opment of the cholinergic fiber patch system in the rat superior colliculus (Mize et al., 1997) is normal after nitroarginine treatment. Retinal projections to the LGN are normal in unmanipulated nNOS knock-out mice or pharmacologically NOS-blocked hamsters (Frost et al., 1994), and pharmacological blockade of NOS does not affect formation of eye-specific layers in the ferret LGN (Cramer et al., 1995a). We also observed normally segregated retinogeniculate projections to the LGN in nitroargininetreated eNOS or nNOS mice (data not shown). Consequently, NO would seem to be involved in only a subset of the synaptic remodeling that takes place in the developing brain as the adult pattern of connectivity emerges.

\section{NO in ocular dominance column formation}

Two previous studies have also examined the requirement for $\mathrm{NO}$ in experience-dependent modification of ocular dominance in cat visual cortex. In these experiments, Ruthazer et al. (1996) and Reid et al. (1996) tested ocular dominance column plasticity in cats after nitroarginine infusion by minipump. Both studies assessed the effects of NOS blockade on the physiologically measured shift in ocular dominance produced by monocular visual deprivation. Both found normal ocular dominance shifts and concluded that NO was not likely to be involved in ocular dominance plasticity in cat visual cortex. Despite these previous findings, we nevertheless thought it worthwhile to examine the role of NO in the "initial" segregation of LGN axons into the ocular dominance columns in layer 4 as opposed to ocular dominance plasticity induced by altering the balance of visual activity between the two eyes. We reasoned that the initial steps in pattern formation might use mechanisms independent from those needed to respond subsequently to alterations of sensory inputs. Second, we assessed the effect of NO blockade anatomically by examining the pattern of segregation of eye input within layer 4 of the visual cortex rather than by examining the ocular dominance of cortical neurons physiologically. Third, we began the NO blockade developmentally much earlier than did these other studies, long before eye opening and 3 weeks before the onset of ocular dominance column formation in ferrets (eye opening is at approximately P32). The previous studies began NOS blockade in 
cats no earlier than P24 (Ruthazer et al., 1996) and as late at P46 (Reid et al., 1996), after the onset of ocular dominance column formation in cats [approximately P21 (LeVay et al., 1978)] and long after eye opening in kittens (eye opening is approximately P8). Nevertheless, blockade of NOS beginning much earlier than in these previous studies and well before eye opening has no discernible effect on the formation of ocular dominance columns in layer 4 of ferret visual cortex.

\section{NOS expression in neurons of the subplate and deep cortical plate is dynamically regulated}

Results described here demonstrate that the density of NADPHdiaphorase-positive neurons in ferret visual subplate is low just after birth but increases dramatically at P25 and P35, just before ocular dominance columns become visible and precisely when thalamic axons are first beginning to segregate. As segregation proceeds, the number of NADPH-diaphorase-positive neurons in the visual cortex and subplate then falls to reach adult levels at approximately the time that column formation in layer 4 is complete. This correlation in the rise in diaphorase expression in visual cortex with the onset of ocular dominance column formation in layer 4 is in accord with observations that NOS expression is developmentally regulated in other structures. NOS expression also correlates with the period of refinement of retinal projections in the chick optic tectum (Williams et al., 1994), mammalian superior colliculus (Mize et al., 1996), and visual thalamus (Cramer et al., 1995b; Guido et al., 1997) and during cerebellar development (Schilling et al., 1994; Li et al., 1997). If NO is not involved directly in the patterning of thalamocortical connectivity, what, then, might the rather dynamic developmental regulation of NOS signify? One known function of NO is to regulate blood flow in capillaries (Goadsby et al., 1992; Lowenstein et al., 1994; Huang et al., 1995). It is conceivable that at these particular times in development, cortical blood flow somehow requires special control or instruction from cortical neurons. In this context it is worth noting that because we administered verapamil to counteract the hypertensive effects of NOS inhibition, cortical vasculature appeared normal in the treated ferrets. (Even in those initial animals that did not receive verapamil, however, ocular dominance columns formed normally and cortical vasculature appeared unaltered.) It is also possible that NO might be involved in establishing aspects of cortical connectivity that we did not examine, such as perhaps the intrinsic horizontal connections that form earlier than the ocular dominance columns (Dalva and Katz, 1994; Weliky and Katz, 1994).

\section{NOS knock-out mice and neuronal pattern formation}

To test the role of NO in the formation of patterned thalamocortical connections in another primary sensory area, we also examined barrel field formation and barrel field plasticity in the somatosensory cortex of mice carrying targeted mutations in nNOS or eNOS. As in ferret visual cortex, so too in mouse neocortex, NADPH-diaphorase is developmentally regulated, including in the subplate (Derer and Derer, 1993) and barrel field (Mitrovic and Schachner, 1996). Within somatosensory cortex, diaphorase expression becomes evident in the neuropil in barrel hollows by P3 and in peaks at P6 and disappears by the end of the second postnatal week (Mitrovic and Schachner, 1996). Thus, in the mouse, diaphorase expression correlates with the critical period for barrel field formation and plasticity (P0-P7) and can even be used to visualize barrels (Franca and Volchan, 1995).

In the rodent barrel cortex, the mechanism of initial pattern formation may not be activity-dependent (Chiaia et al., 1992; Henderson et al., 1992), whereas barrel field plasticity most likely is (Schlaggar et al., 1993) because application of the NMDA receptor blocker APV significantly reduces reorganization of thalamocortical afferent input in response to peripheral insult. Consequently, both barrel field formation and plasticity were tested here. Even though we blocked the activity of the remaining isoforms of NOS in nNOS or eNOS homozygous knock-out mice by making daily nitroarginine injections, we found that both barrel field formation and barrel field plasticity were normal in whisker-ablated mice. It should be noted that the mice used for NOS activity assays were not the same mice as those used for barrel field assessment. Gathering both types of information from the identical animal was technically impossible because of the tissue requirements of the NOS enzymatic activity assay. Nevertheless, given the profound blockade and small variability in NOS activity in the brains that were assayed for NOS activity after nitroarginine treatment (Fig. 8), we think it unlikely that any of the animals examined for barrel formation or plasticity escaped complete blockade. Thus again, as with the formation of ocular dominance columns, we are forced to conclude that NO is unlikely to play a role in the formation of the adult pattern of connections in the mouse somatosensory system.

The preservation of neuronal patterning events in NOSblocked mice is also consistent with a preservation of some forms of hippocampal LTP in double endothelial and neuronal knockout mice (Son et al., 1996). Although LTP is normal in single knock-out animals, LTP is reduced in the stratum radiatum of double knock-out animals (O’Dell et al., 1994; Son et al., 1996). However, LTP in the stratum oriens is preserved and is resistant to NOS block. Our observations and those of Ruthazer et al. (1996) and Reid et al. (1996) would imply that synaptic strengthening in the cortex during development may also involve an NO-independent form of LTP. Indeed, Friedlander and colleagues have shown that synaptic potentiation in cat visual cortex is NO-dependent in adults (Harsanyi and Friedlander, 1997a) but not during development (Harsanyi and Friedlander, 1997b). Thus, the nervous system may use differing strategies at different times and places to regulate and maintain synaptic connectivity.

\section{REFERENCES}

Allendoerfer KL, Shatz CJ (1994) The subplate, a transient neocortical structure: its role in the development of connections between thalamus and cortex. Annu Rev Neurosci 17:185-218.

Antonini A, Shatz CJ (1990) Relation between putative transmitter phenotypes and connectivity of subplate neurons during cerebral cortical development. Eur J Neurosci 2:744-761.

Bear MF, Press WA, Connors BW (1992) Long-term potentiation in slices of kitten visual cortex and the effects of NMDA receptor blockade. J Neurophysiol 67:841-851.

Bredt DS (1995) Molecular characterization of nitric oxide synthase. In: Neuroscience perspectives: nitric oxide in the nervous system. (Vincent SR, ed). San Diego: Academic.

Bredt DS, Snyder SH (1990) Isolation of nitric oxide synthetase, a calmodulin-requiring enzyme. Proc Natl Acad Sci USA 87:682-685.

Bredt DS, Hwang PM, Snyder SH (1990) Localization of nitric oxide synthase indicating a neural role for nitric oxide. Nature 347:768-770.

Bredt DS, Glatt CE, Hwang PM, Fotuhi M, Dawson TM, Snyder SH (1991) Nitric oxide synthase protein and mRNA are discretely localized in neuronal populations of the mammalian CNS together with NADPH diaphorase. Neuron 7:615-624.

Brenman JE, Chao DS, Gee SH, McGee AW, Craven SE, Santillano DR, Wu Z, Huang F, Xia H, Peters MF, Froehner SC, Bredt DS (1996) Interaction of nitric oxide synthase with the postsynaptic density protein PSD-95 and alpha1-syntrophin mediated by PDZ domains. Cell $84: 757-767$ 
Brenman JE, Xia H, Chao DS, Black SM, Bredt DS (1997) Regulation of neuronal nitric oxide synthase through alternative transcripts. Dev Neurosci 19:224-231.

Cabelli RJ, Hohn A, Shatz CJ (1995) Inhibition of ocular dominance column formation by infusion of NT-4/5 or BDNF. Science 267:1662-1666.

Cabelli RJ, Shelton DL, Segal RA, Shatz CJ (1997) Blockade of endogenous ligands of trkB inhibits formation of ocular dominance columns. Neuron 19:63-76.

Chiaia NL, Fish SE, Bauer WR, Bennett-Clarke CA, Rhoades RW (1992) Postnatal blockade of cortical activity by tetrodotoxin does not disrupt the formation of vibrissa-related patterns in the rat's somatosensory cortex. Brain Res Dev Brain Res 66:244-250.

Chun JJ, Shatz CJ (1989a) The earliest-generated neurons of the cat cerebral cortex: characterization by MAP2 and neurotransmitter immunohistochemistry during fetal life. J Neurosci 9:1648-1667.

Chun JJ, Shatz CJ (1989b) Interstitial cells of the adult neocortical white matter are the remnant of the early generated subplate neuron population. J Comp Neurol 282:555-569.

Chun JJ, Nakamura MJ, Shatz CJ (1987) Transient cells of the developing mammalian telencephalon are peptide-immunoreactive neurons. Nature 325:617-620.

Crair MC, Malenka RC (1995) A critical period for long-term potentiation at thalamocortical synapses. Nature 375:325-328.

Crair MC, Gillespie DC, Stryker MP (1998) The role of visual experience in the development of columns in cat visual cortex. Science 279:566-570.

Cramer KS, Angelucci A, Sur M (1995a) Inhibition of nitric oxide synthase does not disrupt formation of eye-specific layers in the ferret lateral geniculate nucleus. Soc Neurosci Abstr 21:1307.

Cramer KS, Moore CI, Sur M (1995b) Transient expression of NADPHdiaphorase in the lateral geniculate nucleus of the ferret during early postnatal development. J Comp Neurol 353:306-316.

Cramer KS, Angelucci A, Hahm JO, Bogdanov MB, Sur M (1996) A role for nitric oxide in the development of the ferret retinogeniculate projection. J Neurosci 16:7995-8004.

Crepel F, Jaillard D (1990) Protein kinases, nitric oxide and long-term depression of synapses in the cerebellum. NeuroReport 1:133-136.

Dalva MB, Katz LC (1994) Rearrangements of synaptic connections in visual cortex revealed by laser photostimulation. Science 265:255-258.

Dawson TM, Bredt DS, Fotuhi M, Hwang PM, Snyder SH (1991) Nitric oxide synthase and neuronal NADPH diaphorase are identical in brain and peripheral tissues. Proc Natl Acad Sci USA 88:7797-7801.

Derer P, Derer M (1993) Ontogenesis of NADPH-diaphorase neurons in the mouse forebrain. Neurosci Lett 152:21-24.

Dwyer MA, Bredt DS, Snyder SH (1991) Nitric oxide synthase: irreversible inhibition by L-NG-nitroarginine in brain in vitro and in vivo. Biochem Biophys Res Commun 176:1136-1141.

East SJ, Garthwaite J (1990) Nanomolar N(G)-nitroarginine inhibits NMDA-induced cyclic GMP formation in rat cerebellum. Eur J Pharmacol 184:311-313.

Finney EM, Stone JR, Shatz CJ (1998) A major glutamatergic projection from subplate into visual cortex during development. J Comp Neurol 398:105-118.

Franca JG, Volchan E (1995) NADPH diaphorase histochemistry as a marker for barrels in rat somatosensory cortex. Braz J Med Biol Res 28:787-790.

Friedlander MJ, Harsanyi K, Dudek S, Kara P (1996a) Developmental mechanisms for regulating signal amplification at excitatory synapses in the neocortex. Prog Brain Res 108:245-262.

Frost DO, Zhang X-F, Huang PL, Fishman MC (1994) Effect of nitric oxide synthase gene knockout or blockade on the development of retinal projections. Soc Neurosci Abstr 20:1318.

Ghosh A (1995) Subplate neurons and the patterning of thalamocortical connections. Ciba Found Symp 193:150-172; discussion 192-199.

Ghosh A, Shatz CJ (1992) Involvement of subplate neurons in the formation of ocular dominance columns. Science 255:1441-1443.

Ghosh A, Shatz CJ (1994) Segregation of geniculocortical afferents during the critical period: a role for subplate neurons. J Neurosci 14:3862-3880.

Goadsby PJ, Kaube H, Hoskin KL (1992) Nitric oxide synthesis couples cerebral blood flow and metabolism. Brain Res 595:167-170.

Guido W, Scheiner CA, Mize RR, Kratz KE (1997) Developmental changes in the pattern of NADPH-diaphorase staining in the cat's lateral geniculate nucleus. Vis Neurosci 14:1167-1173.
Harsanyi K, Friedlander MJ (1997a) Transient synaptic potentiation in the visual cortex. I. Cellular mechanisms. J Neurophysiol 77:1269-1283.

Harsanyi K, Friedlander MJ (1997b) Transient synaptic potentiation in the visual cortex. II. Developmental regulation. J Neurophysiol 77:1284-1293.

Henderson TA, Woolsey TA, Jacquin MF (1992) Infraorbital nerve blockade from birth does not disrupt central trigeminal pattern formation in the rat. Brain Res Dev Brain Res 66:146-152.

Holscher C (1997) Nitric oxide, the enigmatic neuronal messenger: its role in synaptic plasticity. Trends Neurosci 20:298-303.

Hope BT, Michael GJ, Knigge KM, Vincent SR (1991) Neuronal NADPH diaphorase is a nitric oxide synthase. Proc Natl Acad Sci USA 88:2811-2814.

Huang EP (1997) Synaptic plasticity: a role for nitric oxide in LTP. Curr Biol 7:R141-R143.

Huang PL, Dawson TM, Bredt DS, Snyder SH, Fishman MC (1993) Targeted disruption of the neuronal nitric oxide synthase gene. Cell 75:1273-1286.

Huang PL, Huang Z, Mashimo H, Bloch KD, Moskowitz MA, Bevan JA, Fishman MC (1995) Hypertension in mice lacking the gene for endothelial nitric oxide synthase. Nature 377:239-242.

Hubel DH, Wiesel TN, LeVay S (1977) Plasticity of ocular dominance columns in monkey striate cortex. Philos Trans R Soc Lond [Biol] 278:377-409.

Jeanmonod D, Rice FL, Van Der Loos H (1977) Mouse somatosensory cortex: development of the alterations in the barrel field which are caused by injury to the vibrissal follicles. Neurosci Lett 6:151-156.

Jeanmonod D, Rice FL, Van der Loos H (1981) Mouse somatosensory cortex: alterations in the barrelfield following receptor injury at different early postnatal ages. Neuroscience 6:1503-1535.

Kantor DB, Lanzrein M, Stary SJ, Sandoval GM, Smith WB, Sullivan BM, Davidson N, Schuman EM (1996) A role for endothelial NO synthase in LTP revealed by adenovirus-mediated inhibition and rescue. Science 274:1744-1748.

Katz LC, Shatz CJ (1996) Synaptic activity and the construction of cortical circuits. Science 274:1133-1138.

Kirkwood A, Dudek SM, Gold JT, Aizenman CD, Bear MF (1993) Common forms of synaptic plasticity in the hippocampus and neocortex in vitro. Science 260:1518-1521.

Kirkwood A, Lee HK, Bear MF (1995) Co-regulation of long-term potentiation and experience-dependent synaptic plasticity in visual cortex by age and experience. Nature 375:328-331.

Kostovic I, Rakic P (1990) Developmental history of the transient subplate zone in the visual and somatosensory cortex of the macaque monkey and human brain. J Comp Neurol 297:441-470.

Law MI, Zahs KR, Stryker MP (1988) Organization of primary visual cortex (area 17) in the ferret. J Comp Neurol 278:157-180.

Lev-Ram V, Makings LR, Keitz PF, Kao JP, Tsien RY (1995) Longterm depression in cerebellar Purkinje neurons results from coincidence of nitric oxide and depolarization-induced $\mathrm{Ca} 2+$ transients. Neuron 15:407-415.

Lev-Ram V, Jiang T, Wood J, Lawrence DS, Tsien RY (1997) Synergies and coincidence requirements between $\mathrm{NO}, \mathrm{cGMP}$, and $\mathrm{Ca} 2+$ in the induction of cerebellar long-term depression. Neuron 18:1025-1038.

LeVay S, Stryker MP, Shatz CJ (1978) Ocular dominance columns and their development in layer 4 of the cat's visual cortex: a quantitative study. J Comp Neurol 179:223-244.

LeVay S, Wiesel TN, Hubel DH (1980) The development of ocular dominance columns in normal and visually deprived monkeys. J Comp Neurol 191:1-51.

Li J, Chen S, Lin RCS, Smith SS (1997) Cerebellar nitric oxide synthase is expressed within granule cell patches innervated by specific mossy fiber terminals: a developmental profile. Dev Neurosci 19:274-282.

Lowenstein CJ, Glatt CS, Bredt DS, Snyder SH (1992) Cloned and expressed macrophage nitric oxide synthase contrasts with the brain enzyme. Proc Natl Acad Sci USA 89:6711-6715.

Lowenstein CJ, Alley EW, Raval P, Snowman AM, Snyder SH, Russell SW, Murphy WJ (1993) Macrophage nitric oxide synthase gene: two upstream regions mediate induction by interferon gamma and lipopolysaccharide. Proc Natl Acad Sci USA 90:9730-9734.

Lowenstein CJ, Dinerman JL, Snyder SH (1994) Nitric oxide: a physiologic messenger. Ann Intern Med 120:227-237.

Luskin MB, Shatz CJ (1985) Studies of the earliest generated cells of the cat's visual cortex: cogeneration of subplate and marginal zones. J Neurosci 5:1062-1075.

Luth HJ, Hedlich A, Hilbig H, Winkelmann E, Mayer B (1995) Postna- 
tal development of NADPH-diaphorase/nitric oxide synthase positive nerve cells in the visual cortex of the rat. J Hirnforsch 36:313-328.

Mitrovic N, Schachner M (1996) Transient expression of NADPH diaphorase activity in the mouse whisker to barrel field pathway. J Neurocytol 25:429-437.

Mize RR, Banfro FT, Scheiner CA (1996) Pre- and postnatal expression of amino acid neurotransmitters, calcium binding proteins, and nitric oxide synthase in the developing superior colliculus. Prog Brain Res 108:313-332.

Mize RR, Scheiner CA, Salvatore MF, Cork RJ (1997) Inhibition of nitric oxide synthase fails to disrupt the development of cholinergic fiber patches in the rat superior colliculus. Dev Neurosci 19:260-273.

Mizukawa K, Vincent SR, McGeer PL, McGeer EG (1988) Reduced nicotinamide adenine dinucleotide phosphate (NADPH)-diaphorasepositive neurons in cat cerebral white matter. Brain Res 461:274-281.

Mooney R, Madison DV, Shatz CJ (1993) Enhancement of transmission at the developing retinogeniculate synapse. Neuron 10:815-825.

Moore PK, Handy RL (1997) Selective inhibitors of neuronal nitric oxide synthase-is no NOS really good NOS for the nervous system? Trends Pharmacol Sci 18:204-211.

Nowicky AV, Bindman LJ (1993) The nitric oxide synthase inhibitor, $\mathrm{N}$-monomethyl-L-arginine, blocks induction of a long-term potentiation-like phenomenon in rat medial frontal cortical neurons in vitro. J Neurophysiol 70:1255-1259.

O'Dell TJ, Hawkins RD, Kandel ER, Arancio O (1991) Tests of the roles of two diffusible substances in long-term potentiation: evidence for nitric oxide as a possible early retrograde messenger. Proc Natl Acad Sci USA 88:11285-11289.

O'Dell TJ, Huang PL, Dawson TM, Dinerman JL, Snyder SH, Kandel ER, Fishman MC (1994) Endothelial NOS and the blockade of LTP by NOS inhibitors in mice lacking neuronal NOS. Science 265:542-546.

Reid SNM, Daw NW, Czepita D, Flavin HJ, Sessa WC (1996) Inhibition of nitric oxide synthase does not alter ocular dominance shifts in kitten visual cortex. J Physiol (Lond) 494:511-517.

Reiling N, Ulmer AJ, Duchrow M, Ernst M, Flad HD, Hauschildt S (1994) Nitric oxide synthase: mRNA expression of different isoforms in human monocytes/macrophages. Eur J Immunol 24:1941-1944.

Ruthazer ES, Baker GE, Stryker MP (1995) Development and pattern of ocular dominance columns in ferret visual cortex. Soc Neurosci Abstr 21:1795.

Ruthazer ES, Gillespie DC, Dawson TM, Snyder SH, Stryker MP (1996) Inhibition of nitric oxide synthase does not prevent ocular dominance plasticity in kitten visual cortex. J Physiol (Lond) 494:519-527.

Sandell JH (1986) NADPH diaphorase histochemistry in the macaque striate cortex. J Comp Neurol 251:388-397.

Schilling K, Schmidt HH, Baader SL (1994) Nitric oxide synthase expression reveals compartments of cerebellar granule cells and suggests a role for mossy fibers in their development. Neuroscience 59:893-903.

Schlaggar BL, Fox K, O'Leary DD (1993) Postsynaptic control of plasticity in developing somatosensory cortex. Nature 364:623-626.

Schuman EM, Madison DV (1991) A requirement for the intercellular messenger nitric oxide in long-term potentiation. Science 254:1503-1506.

Shatz CJ (1990) Impulse activity and the patterning of connections during CNS development. Neuron 5:745-756.

Silvagno F, Xia H, Bredt DS (1996) Neuronal nitric-oxide synthase-mu, an alternatively spliced isoform expressed in differentiated skeletal muscle. J Biol Chem 271:11204-11208.
Son H, Hawkins RD, Martin K, Kiebler M, Huang PL, Fishman MC, Kandel ER (1996) Long-term potentiation is reduced in mice that are doubly mutant in endothelial and neuronal nitric oxide synthase. Cell 87:1015-1023.

Stryker MP, Harris WA (1986) Binocular impulse blockade prevents the formation of ocular dominance columns in cat visual cortex. J Neurosci 6:2117-2133

Stryker MP, Strickland SL (1984) Physiological segregation of ocular dominance columns depends on the pattern of afferent electrical activity. Invest Opthalmol Vis Sci [Suppl] 25:278.

Van der Loos H, Woolsey TA (1973) Somatosensory cortex: structural alterations following early injury to sense organs. Science 179:395-398.

Vincent SR, Kimura H (1992) Histochemical mapping of nitric oxide synthase in the rat brain. Neuroscience 46:755-784.

Wang JH, Ko GY, Kelly PT (1997) Cellular and molecular bases of memory: synaptic and neuronal plasticity. J Clin Neurophysiol 14:264-293.

Wang T, Xie Z, Lu B (1995) Nitric oxide mediates activity-dependent synaptic suppression at developing neuromuscular synapses. Nature 374:262-266.

Weliky M, Katz LC (1994) Functional mapping of horizontal connections in developing ferret visual cortex: experiments and modeling. J Neurosci 14:7291-7305.

Weller WL, Johnson JI (1975) Barrels in cerebral cortex altered by receptor disruption in newborn, but not in five-day-old mice (Cricetidoe and Muridae). Brain Res 83:504-508.

Wiesel TN, Hubel DH (1965) Comparison of the effects of unilateral and bilateral eye closure on cortical unit responses in kittens. J Neurophysiol 28:1029-1040.

Williams CV, Nordquist D, McLoon SC (1994) Correlation of nitric oxide synthase expression with changing patterns of axonal projections in the developing visual system. J Neurosci 14:1746-1755.

Williams JH (1996) Retrograde messengers and long-term potentiation: a progress report. J Lipid Mediat Cell Signal 14:331-339.

Woolsey TA, Wann JR (1976) Areal changes in mouse cortical barrels following vibrissal damage at different postnatal ages. J Comp Neurol 170:53-66.

Wu HH, Williams CV, McLoon SC (1994) Involvement of nitric oxide in the elimination of a transient retinotectal projection in development. Science 265:1593-1596.

Wu HH, Waid DK, McLoon SC (1996) Nitric oxide and the developmental remodeling of retinal connections in the brain. Prog Brain Res 108:273-286.

Xia H, Bredt DS (1996) Cloned and expressed nitric oxide synthase proteins. Methods Enzymol 268:427-436.

Yan XX, Ribak CE (1997) Prenatal development of nicotinamide adenine dinucleotide phosphate-diaphorase activity in the human hippocampal formation. Hippocampus 7:215-231.

Yan XX, Garey LJ, Jen LS (1996) Prenatal development of NADPHdiaphorase-reactive neurons in human frontal cortex. Cereb Cortex 6:737-745.

Zhuo M, Small SA, Kandel ER, Hawkins RD (1993) Nitric oxide and carbon monoxide produce activity-dependent long-term synaptic enhancement in hippocampus. Science 260:1946-1950. 